\title{
Biologically Controlled Mineralization of Magnetic Iron Minerals by Magnetotactic Bacteria
}

\author{
Dennis A. Bazylinski and Richard B. Frankel
}

The biomineralization of several magnetic iron minerals, including the iron oxide magnetite $\left(\mathrm{Fe}_{3} \mathrm{O}_{4} ; \mathrm{Fe}^{2+} \mathrm{Fe}_{2}{ }^{3+} \mathrm{O}_{4}\right)$ and the iron sulfides greigite $\left(\mathrm{Fe}_{3} \mathrm{~S}_{4}\right)$ and pyrrhotite $\left(\mathrm{Fe}_{7} \mathrm{~S}_{8}\right)$, can be mediated by bacteria as well as by other organisms. These minerals are known to be synthesized by procaryotes in one of two fundamentally different modes of biomineralization. The first is uncontrolled mineral formation, called biologically induced mineralization (BIM) (92), while the second is directed-mineral formation, termed biologically controlled mineralization (BCM), also referred to as organic matrix-mediated mineralization (92) or boundary-organized biomineralization (96). Whereas in BIM the organism does not appear to control the biomineralization process, in BCM the organism exerts a high degree of control over the mineralization process.

Different physiological types of bacteria are responsible for BIM and BCM of magnetic minerals. Dissimilatory iron-reducing and dissimilatory sulfate-reducing bacteria cause the formation of magnetite and greigite, respectively, as well as many other nonmagnetic iron minerals, by BIM processes. Among the procaryotes, only the magnetotactic bacteria biomineralize magnetite and greigite by BCM. There is no apparent function to the magnetite and greigite particles produced via BIM by microorganisms. However, there is ecological, evolutionary, and perhaps physiological significance to the BCM particles produced by the magnetotactic bacteria. Additionally, the biomineralization of magnetic minerals by bacteria can be an important source of fine-grained $(<1 \mu \mathrm{m})$ magnetic material in sediments and soils. which contributes to the paleomagnetic record of ancient geomagnetic field behavior and to the mineral magnetic record of paleoclimate changes $(37.38 .94,137)$. It is important to be able to discern the differences between particle types so as to be able to recognize biogenic magnetic mineral particles and also to determine

Dennis A. Bazylinski - Department of Microbiology, lowa State Universily, Ames, IA 50011. Richard B. Frankel • Department of Physics, California Polytechnic State University. San Luis Obispo. CA 93407. 
which types of microorganisms are responsible for the deposition of the magnetic mineral particles. In addition, recent mineral discoveries in the Martian meteorite ALH84001 (117), which have been interpreted as evidence for ancient life on Mars, make this need even greater. The purpose of this chapter is to examine and review features of BIM- and BCM-type magnetic particles, to describe the microorganisms that produce magnetic minerals (focusing mainly on the magnetotactic bacteria), and to describe the biomineralization processes involved in the synthesis of magnetic minerals. We also review the physics and function of magnetotaxis in light of recent findings.

\section{BIOLOGICALLY INDUCED MINERALIZATION}

In BIM, biomineralization occurs extracellularly as a result of metabolic processes of the organism and subsequent chemical reactions involving metabolic byproducts. In most cases, the organisms secrete a metabolic product(s) that reacts with a specific ion or compound in the surrounding environment, resulting in the production of extracellular mineral particles. Thus, mineralization is an unintended consequence of metabolic activities that are characterized by being poorly crystallized, having a broad particle size distribution, and lacking specific crystalline morphologies. In addition, the lack of control over biomineralization often results in decreased mineral specificity and/or the inclusion of impurities in the particles. Because BIM processes are not controlled by the organisms and because most mineral particles produced by BIM can also be produced chemically with the same crystallochemical features without bacterial catalysts (103), BIM is equivalent to nonbiogenic mineralization under the same environmental conditions. Particles formed by BIM are therefore likely to be indistinguishable from particles produced nonbiogenically in inorganic chemical reactions under similar conditions, such as during pedogenesis (93). The implication is that in BIM the minerals nucleate in solution or form from poorly crystallized mineral species already present. However. bacterial surfaces can also act as important sites for the adsorption of ions and mineral nucleation $(25,78)$. The importance of bacterial surfaces in most cases of BIM has not been elucidated.

\section{Magnetite}

Magnetite can be formed by the dissimilatory iron-reducing bacteria and probably by other microorganisms that reduce iron in nondissimilatory, non-energyyielding reactions as well. Dissimilatory iron-reducing microorganisms respire with oxidized iron, Fe(III), in the form of amorphous Fe(III) oxyhydroxide $(87,88)$ under anaerobic conditions and secrete reduced iron, Fe(II), into the surrounding environment, where it subsequently reacts with excess Fe(III) oxyhydroxide to form magnetite. Magnetite particles, formed extracellularly by these microorganisms, are (i) irregular in shape with a relatively broad size distribution, with most particles being in the superparamagnetic size range $(<35 \mathrm{~nm})$, and (ii) poorly crystallized $(124,166)$. 
Many different species and physiological types of bacteria reduce Fe(III) (see reference 86 for a complete list and chapter 2 of this volume for a more detailed discussion of these microorganisms). However, it seems that only a handful of these organisms conserve energy and grow from the reduction of this environmentally abundant terminal electron acceptor (125) and produce magnetite. Geobacter metallireducens and Shewanella (formerly Alteromonas) putrefaciens are the most extensively studied members of this group and are phylogenetically associated with the $\delta$ and $\gamma$ subdivisions, respectively, of the Proteobacteria $(84,89,125)$, a diverse, vast assemblage of gram-negative procaryotes in the domain Bacteria (196). Shewanella and Geobacter species appear to be very common in aquatic and sedimentary environments (43), and several new Fe(III) species of these genera have been isolated in recent years $(36,152)$, suggesting that members of these genera may be the most environmentally significant microbes involved in Fe(III) reduction and extracellular magnetite precipitation. Although magnetite formation by BIM has been demonstrated only in cultures of the mesophiles Shewanella, Geobacter. (87, 91), and Geothrix fermentans (J. D. Coates, personal communication), several thermophiles, including the Fe(III)-reducing bacterium strain TOR-39 (198), the archaeon Pyrobaculum islandicum (185), and the bacterium Thermotoga maritima (185), and mixed cultures or consortia containing Fe(III) reducers $(15,81,197)$, it is likely that magnetite can be produced by a pure culture of any $\mathrm{Fe}$ (III)-reducing bacterium, regardless of whether the organism can grow with Fe(III), under suitable environmental conditions when the Fe(III) source is insoluble amorphous Fe(III) oxides. It should also be noted that black, unidentified magnetic precipitates commonly observed forming in enrichment cultures or pure cultures of Fe(III) reducing bacteria containing insoluble amorphous Fe(III) oxide as the Fe(III) source (see, e.g., references 64,163 , and 164) probably consist of primarily magnetite. The halotolerant, facultatively anaerobic, iron-reducing bacterium described by Rossello-Mora et al. (152) most probably produces nonstoichiometric particles of magnetite with a composition intermediate between those of magnetite and maghemite $\left(\gamma-\mathrm{Fe}_{2} \mathrm{O}_{3}\right)(68)$. S. putrefaciens is able to reduce and grow on the $\mathrm{Fe}$ (III) in magnetite which contains both $\mathrm{Fe}(\mathrm{II})$ and $\mathrm{Fe}(\mathrm{III})$ (79), while it appears that $G$. metallireducens is unable to do so (90). Thus, Shewanella species may be also be important in the dissolution as well as the formation of magnetite in sediments.

Cells of one magnetotactic species, Magnetospirillum magnetotacticum, reduce iron in growing cultures, and there is some evidence that iron reduction may be linked to energy conservation and growth in this bacterium (66). Extracellular BIMtype magnetite has never been observed in cultures of this organism, although, like all magnetite-producing magnetotactic species, cells of $M$. magnetotacticum synthesize intracellular particles of magnetite (55) through BCM.

\section{Greigite and Pyrrhotite}

Some anaerobic sulfate-reducing bacteria produce particles of the magnetic iron sulfide greigite by using BIM processes. In this case, the sulfate-reducing bacteria respire with sulfate anaerobically, releasing hydrogen sulfide. The sulfide ions react with excess iron present in the external enviromment, forming magnetic particles 
of greigite and pyrrhotite as well as a number of other nonmagnetic iron sulfides including mackinawite (approximately FeS), pyrite (cubic FeS ${ }_{2}$ ), and marcasite (orthorhombic $\left.\mathrm{FeS}_{2}\right)(58,148,149)$. Mineral species formed in these bacterially catalyzed reactions appear to be dependent on the $\mathrm{pH}$ of the growth medium, the incubation temperature, the $E_{h}$ (redox potential), the presence of specific oxidizing and reducing agents, and the type of iron source in the growth medium. For example, cells of Desulfovibrio desulfuricans produce greigite when grown in the presence of ferrous salts but not when the iron source is goethite, $\mathrm{FeO}(\mathrm{OH})(148)$. Microorganisms can clearly modify $\mathrm{pH}, \mathrm{E}_{\mathrm{l}}$, etc., during growth. Berner (16-19) reported the chemical synthesis of a number of iron sulfide minerals including tetragonal FeS, marcasite, a magnetic cubic iron sulfide of the spinel type (probably greigite), pyrrhotite, amorphous FeS, and even framboidal pyrite, a globular form of pyrite that was once thought to represent fossilized bacteria $(47,85)$. Not surprisingly, Rickard $(148,149)$ concluded that extracellular biogenic and abiogenic particles of iron sulfides could not be distinguished from one another. However, none of the magnetic iron sulfides produced by the sulfate-reducing bacteria appear to have been examined in any detail using modern electron microscopy techniques.

The ubiquitous, anaerobic sulfate-reducing bacteria are a physiological group of microorganisms that are phylogenetically and morphologically very diverse and include species in the domains Bacteria ( $\delta$ subdivision of Proteobacteria and grampositive group) and Archaea. Most of the studies on the extracellular production of iron sulfides by sulfate-reducing bacteria, including the studies described above, involved the motile gram-negative bacterium Desulfovibrio desulfuricans, a member of the $\delta$ subgroup of the Proteobacteria. However, because all sulfate-reducing bacteria respire with sulfate and release sulfide ions, it is likely that all species, regardless of phylogeny or classification, produce iron sulfide minerals through BIM under appropriate environmental conditions when excess iron is available. The sulfate-reducing magnetotactic bacterium strain RS-1 can produce extracellular magnetic iron sulfides, presumably through BIM, as well as intracellular particles of magnetite through BCM (153). The iron sulfides produced by this microorganism, however, were not identified.

\section{Other Nonmagnetic Iron Minerals}

Other nonmagnetic iron minerals formed by BIM have been observed in bacterial cultures. In these cases, Fe(II), excreted by iron-reducing bacteria during the reduction of Fe(III), reacts with anions present in the growth medium. Two examples are carbonate, which reacts with $\mathrm{Fe}(\mathrm{II})$ to form the mineral siderite $\left(\mathrm{FeCO}_{3}\right)$, and phosphate, which reacts with $\mathrm{Fe}(\mathrm{II})$ to form vivianite $\left[\mathrm{Fe}_{3}\left(\mathrm{PO}_{4}\right)_{2} \cdot 8 \mathrm{H}_{2} \mathrm{O}\right]$. Siderite was observed in cultures of Geobacter metallireducens along with magnetite when the organism was grown in a bicarbonate buffering system $(90,166)$, while only vivianite was produced, with no production of magnetite or siderite, by the same organism when Fe(III) citrate was provided as the terminal electron acceptor (87, 90). Growing cells of the magnetotactic species Magnetospirillum magnetotacticum produced significant amounts of extracellular, needle-like crystals of vivianite while actively reducing $\mathrm{Fe}($ III) in the form of $\mathrm{Fe}(\mathrm{III})$ oxyhydroxides (28). Although it is 
likely that many other iron-reducing bacteria form siderite and vivianite, most microbiologists are not looking for such compounds during routine culturing.

\section{BIOLOGICALLY CONTROLLED MINERALIZATION}

In BCM, the organisms exert a great degree of crystallochemical control over the nucleation and growth of the mineral particles. For the most part, the minerals are directly synthesized at a specific location in or on the cell and only under specific conditions. The mineral particles produced by bacteria in BCM are characterized by being well-ordered crystals (not anorphous) and having narrow size distributions and very specific, consistent particle morphologies. Because of these features, BCM processes are likely to be under specific metabolic and genetic control. In the microbial world, the most widely recognized example of BCM is magnetosome production by the magnetotactic bacteria.

\section{Magnetotactic Bacteria}

\section{Classification, Phylogeny, and General Features}

The magnetotactic bacteria represent a heterogeneous group of procaryotes that align and swim along the Earth's geomagnetic field lines $(27,29)$. They have a myriad of cellular morphologies including coccoid, rod shaped, vibrioid, spirilloid (helical), and even multicellular $(3,27,29,49,150)$. Thus, the term "magnetotactic bacteria" has no taxonomic significance and should be interpreted as a term for a collection of diverse bacteria that possess the apparently widely distributed trait of magnetotaxis (3). While all that have been examined to date are gram-negative members of the domain Bacteria, the possibility of the existence of a magnetotactic member of the Archaea cannot be excluded.

Despite the greal diversity of the magnetotactic bacteria, they all share several features: (i) they are all motile (although this does not preclude the possibility of the existence of nonmotile bacteria that synthesize magnetosomes, which, by definition. would be magnetic but not magnetotactic): (ii) they all exhibit a negative tactic and/or growth response to atmospheric concentrations of oxygen; and (iii) they all possess a number of intracellular structures called magnetosomes. Magnetosomes are the hallmark feature of the magnetotactic bacteria and are responsible for their behavior in magnetic fields. The bacterial magnetosome consists of a single-magnetic-domain crystal of a magnetic iron mineral enveloped by a membrane (2). Magnetotactic bacteria generally synthesize particles of either magnetite or greigite. There is one known exception: a large, rod-shaped magnetotactic bacterium collected from the Pettaquamscutt Estuary was found to contain both magnetite and greigite $(9,13)$.

Phylogenetic analysis, based on the sequences of 16S rRNA genes of many cultured and uncultured magnetotactic bacteria, initially showed that the magnetiteproducing strains were associated with the $\alpha$ subdivision of the Proteobacteria (34. $40,46,155,169$ ), while an uncultured greigite-producing bacterium was found to be associated with the sulfate-reducing bacteria in the $\delta$ subdivision of the Proteobacteria (40). Since the different subdivisions of the Proteobacteria are considered 
to be coherent, distinct evolutionary lines of descent (194, 196), DeLong et al. (40) proposed that the evolutionary origin of magnetotaxis was polyphyletic and that magnetotaxis based on iron oxide (magnetite) production evolved separately from that based on iron sulfide (greigite) production. However, more recent studies (158, 170-172) have shown that many but not all magnetite-producing magnetotactic bacteria are associated with the $\alpha$ subgroup of the Proteobacteria. Kawaguchi et al. (74) showed that a cultured, magnetite-producing sulfate-reducing magnetotactic bacterium, strain RS-1 (153), is a member of the $\delta$ subgroup of the Proteobacteria, while Spring et al. (168) described an uncultured magnetite-producing magnetotactic bacterium called Magnetobacterium bavaricum, which is in the domain Bacteria but apparently is not phylogenetically associated with the Proteobacteria. These results suggest that magnetotaxis as a trait may have evolved several times and, moreover, may indicate that there is more than one biochemical-chemical pathway for the BCM of magnetic minerals by magnetotactic bacteria.

\section{Ecology}

Magnetotactic bacteria are ubiquitous in aquatic habitats that are close to neutrality in $\mathrm{pH}$ and that are not thermal, strongly polluted, or well oxygenated (27, 121). They are cosmopolitan in distribution (27), and because magnetotactic bacterial cells are easy to observe and separate from mud and water by exploiting their magnetic behavior using common laboratory magnets (121), there are frequent continued reports of their occurrence in various, sometimes exotic, freshwater and marine locations (see, e.g., references 1, 72, 107, and 134). Magnetotactic bacteria are generally found in the largest numbers at the oxic-anoxic transition zone (OATZ), also referred to as the microaerobic zone or the redoxocline (3). In many freshwater habitats, the OATZ is located at or just below the sediment/water interface. However, in some brackish-to-marine systems, the OATZ is found or is seasonally located in the water column, as shown in Fig. 1. The Pettaquamscutt Estuary (Narragansett Bay, R.I.) (44) and Salt Pond (Woods Hole, Mass.) (186. 187) are good examples of the latter situation. Hydrogen sulfide, produced by sulfate-reducing bacteria in the anaerobic zone and sediment, diffuses upward and oxygen diffuses downward from the surface, resulting in a double, vertical chemical concentration gradient (Fig. 1) with a coexisting redox gradient. In addition, strong pycnoclines and other physical factors, probably including the microorganisms themselves, stabilize the vertical chemical gradients and the resulting OATZ.

Many types of magnetotactic bacteria are found at both the Pettaquamscutt Estuary (9) and Salt Pond (D. A. Bazylinski, unpublished results). Generally, the magnetite-producing magnetotactic bacteria prefer the OATZ proper (Fig. 1) and behave as microaerophiles. Information obtained from culture experiments supports this observation. Two strains of magnetotactic bacteria have been isolated from the Pettaquamscutt Estuary. One is a vibrio designated strain MV-2 (40, 118), and the other is a coccus designated strain $\mathrm{MC}-\mathrm{l}(40,52,119)$. Both strains grow as microaerophiles, although strain MV-2 can also grow anaerobically with nitrous oxide $\left(\mathrm{N}_{2} \mathrm{O}\right)$ as a terminal electron acceptor. Other cultured magnetotactic bacterial strains, including spirilla $(106,155,158)$ and rods $(153)$, are microaerophiles or anaerobes or both. The greigite producers are probably anaerobes preferring the 


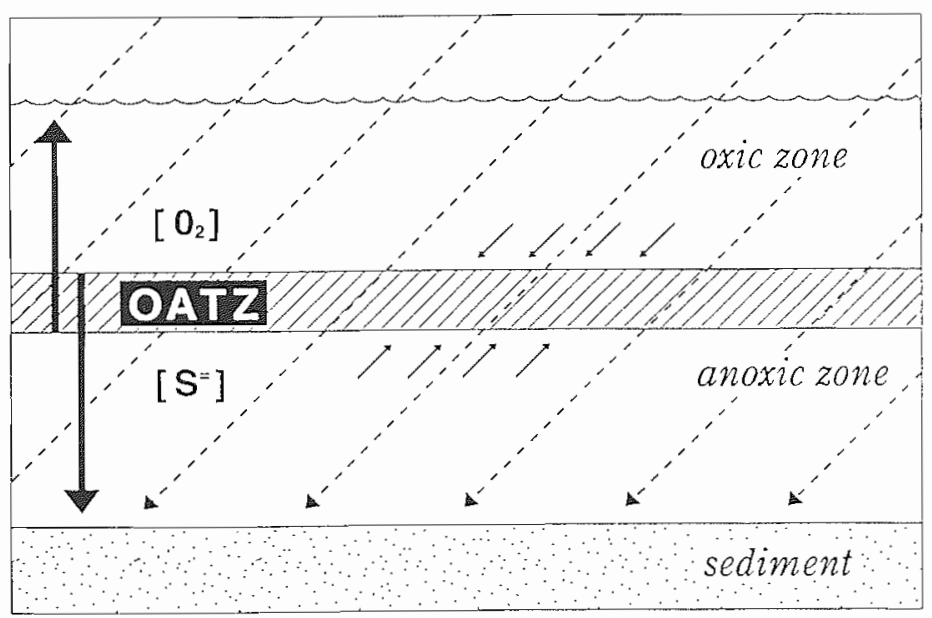

Figure 1. Depiction of the OATZ in the water column as typified by Salt Pond (Woods Hole, Mass.). Note the inverse double concentration gradients of oxygen $\left(\left[\mathrm{O}_{2}\right]\right)$ diffusing from the surface and sulfide $\left(\left[\mathrm{S}^{-}\right]\right.$) generated by sulfate-reducing bacteria in the anaerobic zone (vertical arrows). Magnetite-producing magnetotactic bacteria exist in their greatest numbers at the OATZ, where microaerobic conditions predominate, and greigite-producers are found just below the OATZ, where $\mathrm{S}^{2-}$ becomes detectable. When polar-magneto-aerotactic, magnetite-producing coccoid cells are above the $\mathrm{OATZ}$ in vertical concentration gradients of $\mathrm{O}_{2}$ and $\mathrm{S}^{-}$(higher $\left[\mathrm{O}_{2}\right]$ than optimal), they swim downward (small arrows above OATZ) along the inclined geonagnetic field lines (dashed lines). When they are below the OATZ (lower $\left[\mathrm{O}_{2}\right.$ ] than optimal), they reverse direction (by reversing the direction of their flagellar motor) and swim upward (small arrows below the OATZ) along the inclined geomagnetic fieid lines. The direction of flagellar rotation is coupled to a acrotactic sensory system that acts as a switch when cells are at a suboptimal position in the graldient as defined in the lext. The magnetotactic spirilla (and other axial magnetoaerotactic microorganisms) align along the geomagnetic field lines and swim up and down, relying on a temporal sensory mechanism of aerolaxis to hind and maintain position at their optimal oxygen concentration at the OATZ.

more sulfidic waters just below the OATZ (Fig. 1), where oxygen is barely or not detectable $(3,7-9)$. No greigite-producing magnetotactic bacterium has been grown in pure culture.

\section{Function and Physics of Magnetotaxis}

There is important physical significance to the size of the magnetosone mineral phase, which is reflected in its physical and magnetic properties. The magnetosome mineral crystals occur in a very narrow size range, from about 35 to $120 \mathrm{~nm}$ (12. 14, 51, 57, 122). Magnetite and greigite particles in this range are stable single magnetic domains $(35,42)$. Smaller particles would be superparamagnetic at ambient temperature and would not have stable, remanent magnetizations. Larger particles would tend to form multiple domains, reducing the remanent magnetization. Thus, by producing single-magnetic-domain particles, cells have maximized the remanent magnetization of the magnetosone mineral phase. 
In most magnetotactic bacteria, the magnetosomes are arranged in one or more chains $(3,14)$. Magnetic interactions between the magnetosome particles in a chain cause their magnetic dipole moments to orient parallel to each other along the chain length. In this chain motif, the total magnetic dipole moment of the cell is simply the sum of the permanent dipole moments of the individual, singlemagnetic-domain magnetosome particles. Magnetic measurements (142), magneticforce microscopy $(147,176)$, and electron holography (45) have confirmed this conclusion and show that the chain of magnetosomes in a magnetotactic bacterium functions like a single magnetic dipole and causes the cell to behave similarly. Therefore, the cell has maximized its magnetic dipole moment by arranging the magnetosomes in chains. The magnetic dipole moment of the cell is generally large enough that its interaction with the Earth's geomagnetic field overcomes the thermal forces tending to randomize the cell's orientation in its aqueous surroundings (50). Magnetotaxis results from the passive alignment of the cell along geomagnetic field lines while it swims. It is important to realize that cells are neither attracted nor pulled toward either geomagnetic pole. Dead cells, like living cells, align along geomagnetic field lines but do not move. In essence, living cells behave like very small, self-propelled magnetic compass needles.

Originally, magnetotactic bacteria were thought to have one of two magnetic polarities, north or south seeking, depending on the magnetic orientation of the magnetic dipoles of the cells with respect to their direction of motion. The vertical component of the inclined geomagnetic field appeared to select for a predominant polarity in each hemisphere by favoring cells whose polarity causes them to migrate down toward the microaerobic sediments and away from potentially toxic concentrations of oxygen in surface waters. This scenario appears to be at least partially true: north-seeking magnetotactic bacteria predominate in the Northern hemisphere, while south-seeking cells predominate in the Southern hemisphere $(30,75)$. At the Equator, where the vertical component of the geomagnetic field is zero, equal numbers of both polarities coexist (54). However, the discovery of stable populations of magnetotactic bacteria existing at specific depths in the water columns of chemically stratified aquatic systems at higher latitudes (9) and the observation that virtually all magnetotactic bacteria in pure culture form microaerophilic bands of cells some distance from the meniscus of the growth medium (52) are not consistent with this original simple model of magnetotaxis. For example, according to this model, persistent North-seeking magnetotactic bacteria in the Northern hemisphere should always be found in the sediments or at the bottom of culture tubes.

Like most other free-swimming bacteria, magnetotactic bacteria propel themselves forward in their aqueous surroundings by rotating their helical flagella (162). Unlike cells of Escherichia coli and other chemotactic bacteria, magnetotactic bacteria do not exhibit the characteristic "run and tumble" motility (3). Because of their magnetosomes, magnetotactic bacteria are oriented and migrate along the local magnetic field B. Some magnetotactic spirilla, such as Magnetospirillum magnetotacticum, swim parallel or antiparallel to $\mathbf{B}$ and form aerotactic bands $(31,167)$ at a preferred oxygen concentration $\left[\mathrm{O}_{2}\right]$. In a homogeneous medium, roughly equal numbers of cells swim in either direction along $\mathbb{B}(31,167)$. This behavior has been termed axial magneto-aerotaxis (52), because the cells use the magnetic field 
as an axis for migration, with aerotaxis determining the direction of migration along the axis. Most microaerophilic bacteria form aerotactic bands at a preferred or optimal $\left[\mathrm{O}_{2}\right]$ where the proton motive force is maximal (199), using a temporal sensory mechanism (159) that samples the local environment as they swim and compares the present $\left[\mathrm{O}_{2}\right]$ with that in the recent past (180). The change in $\left[\mathrm{O}_{2}\right]$ with time determines the sense of flagellar rotation (105). The behavior of individual cells of $M$. magnetotacticum in aerotactic bands in thin capillaries is consistent with the temporal sensory mechanism (52). Thus, cells in the band which are moving away from the optimal $\left[\mathrm{O}_{2}\right]$, to either higher or lower $\left[\mathrm{O}_{2}\right]$, eventually reverse their swimming direction and return to the band.

In contrast, ubiquitous freshwater and marine bilophotrichously flagellated (having two flagellar bundles on one hemisphere of the cell) magnetotactic cocci (26, $52,120,121)$ and some other magnetotactic strains swim persistently in a preferred direction relative to $\mathbf{B}$ when examined microscopically in wet mounts $(26,52)$. In fact, this persistent swimming of cocci in a preferred direction led to the discovery of magnetotaxis in bacteria (26). However, it has recently been shown that magnetotactic cocci in oxygen gradients, like cells of $M$. magnetotacticum, can swim in both directions along $\mathbb{B}$ without turning around (52). The cocci also form microaerophilic, aerotactic bands, like cells of $M$. magnetotacticum, and seek a preferred $\left[\mathrm{O}_{2}\right]$ along the concentration gradient (52). However, while the aerotactic behavior of $M$. magnetotacticum is consistent with the temporal sensory mechanism, the aerotactic behavior of the cocci is not. Instead, their behavior is consistent with a two-state aerotactic sensory model in which the $\left[\mathrm{O}_{2}\right]$ determines the sense of the flagellar rotation and hence the swimming direction relative to $\mathbf{B}$. Cells at $\left[\mathrm{O}_{2}\right]$ higher than optimum swim persistently in one direction relative to $\mathbf{B}$ until they reach a low $\left[\mathrm{O}_{2}\right]$ threshold, where they reverse flagellar rotation and hence swimming direction relative to $\mathbb{B}$. They continue until they reach a high $\left[\mathrm{O}_{2}\right]$ threshold, where they reverse again. In wet mounts, the $\left[\mathrm{O}_{2}\right]$ is above optimal and the cells swim persistently in one direction relative to $\mathbf{B}$. This model, termed polar magneto-aerotaxis (52), accounts for the ability of the magnetotactic cocci to migrate to and maintain position at the preferred $\left[\mathrm{O}_{2}\right]$ at the OATZ in chemically stratified, semianaerobic basins. An assay using chemical gradients in thin capillaries has been developed that distinguishes between axial and polar magnetoaerotaxis (53).

For both aerotactic mechanisms, migration along magnetic field lines reduces a three-dimensional search problem to a one-dimensional search problem. Thus, magnetotaxis is presumably advantageous to motile microorganisms in vertical concentration gradients because it increases the efficiency of finding and maintaining an optimal position in such concentration gradients, in this case, vertical oxygen gradients (Fig. 1). It is likely that there are other forms of magnetically assisted chemotaxis to molecules or ions other than oxygen, such as sulfide, or magnetically assisted redox- or phototaxis in bacteria that inhabit the anaerobic zone (e.g.. greigite producers) in chemically stratified waters and sediments.

$1 t$ is important to realize that the function of cellular magnetotaxis described above appears to be a consequence of the cell possessing magnetosomes. Bacteria can only react to a stimulus and therefore do not make the magnetosomes for 
magnetotaxis (a teleological argument). In addition, there is some conflicting evidence about the role of magnetosomes in magnetotaxis. For example, many obligately microaerophilic bacteria find and maintain an optimal position at the OATZ without the help of magnetosomes, cultured magnetotactic bacteria form microaerophilic bands of cells in the absence of a magnetic field, and some greigiteproducing magnetotactic bacteria collected from the environment produce gas vacuoles, presumably for buoyancy (4). Thus, it appears likely that the enormous amount of iron uptake and magnetosome production is somehow also linked to the physiology of the cell and to other, as yet unknown, cellular functions.

\section{Composition and Morphology of the Magnetosome Mineral Phase}

As stated above, there are two compositional types of magnetosomes in magnetotactic bacteria: iron oxides and iron sulfides. The mineral composition of the magnetosome is probably under genetic control in that cells of several cultured magnetite-producing magnetotactic bacteria still synthesize an iron oxide (magnetite) and not an iron sulfide (grigite) even when hydrogen sulfide is present in the growth medium $(118,119)$. The iron oxide-type magnetosomes consist solely of magnetite. The particle morphology of magnetite varies but is consistent within cells of a single bacterial species or strain (12). Three general morphologies of magnetite particles have been observed in magnetotactic bacteria using transmission electron microscopy (TEM) $(12,29,102,173)$. These are include (i) roughly cuboidal $(2,98)$, (ii) parallelepipedal (rectangular in the horizontal plane of projection) $(10,120,121,183)$, and (iii) tooth, bullet, or arrowhead shaped (anisotropic) (100, 101, 181). Examples are shown in Fig. 2.

High-resolution TEM and selected area electron diffraction studies have revealed that the magnetite particles within magnetotactic bacteria are of high structural perfection and have been used to determine their idealized morphologies (98-101, $108,118,119)$. These morphologies are all derived from combinations of $\{111\}$, $\{110\}$, and $\{100\}$ forms with suitable distortions (41). The roughly cuboidal particles are cubo-octahedra $(\{100\}+\{111\})$, and the parallelepipedal particles are either truncated pseudo-hexahedral or pseudo-octahedral prisms. Examples are shown in Figs. 3a to $\mathrm{d}$. The cubo-octahedral crystal morphology preserves the symmetry of the face-centered cubic spinel structure; i.e., all equivalent crystal faces develop equally. The pseudo-hexahedral and pseudo-octahedral prismatic particles represent anisotropic growth in which equivalent faces develop unequally $(41,97)$.

The synthesis of the tooth-, bullet-, and arrowhead-shaped magnetite particles (Fig. 2c) appears to be more complex than that of the other forms. They have been examined by high-resolution TEM in one uncultured organism $(100,101)$, and their idealized morphology suggests that the growth of these particles occurs in two stages. The nascent crystals are cubo-octahedra which subsequently elongate along the [1 11 ] axis parallel to the chain direction.

Whereas the cubo-octahedral form of magnetite can occur in inorganically formed magnetites (138), the prevalence of elongated pseudo-hexahedral or pseudooctahedral habits in magnetosome crystals imply anisotropic growth conditions, e.g., a temperature gradient, a concentration gradient, or anisotropic ion flux (97). 

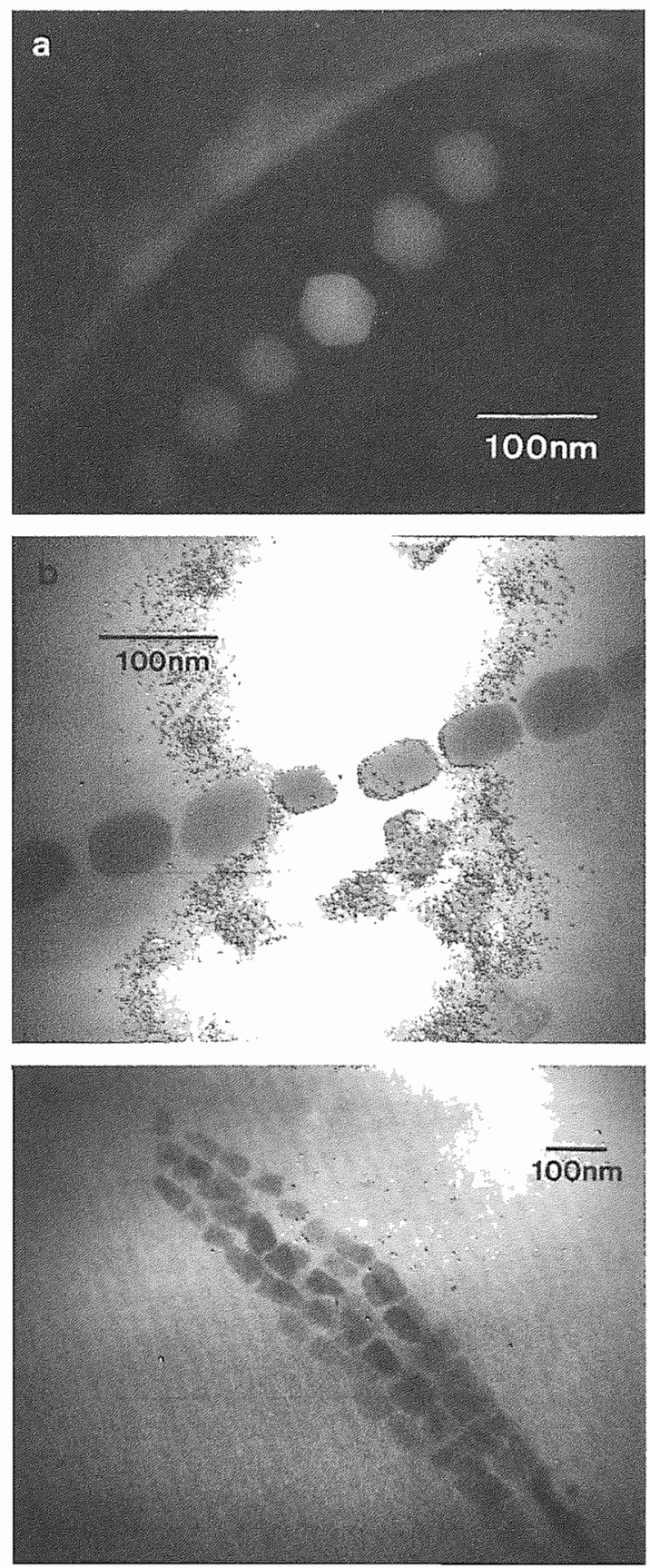

Figure 2. Morphologies of intracellular magnetite $\left(\mathrm{Fe}_{3} \mathrm{O}_{4}\right.$ ) particles produced by magnetotactic bacteria collected from the OATZ of the Petaquamscull Estuary. (a) Dark-field scanning-transmission electron micrograph (STEM) of a chatin of cubooctahedra in cells of an unidentified rod-shaped bacterim, viewed along a ll li zone axis for which the particle projections appear hexagonal. (b) Brighth-field STEM of a chain of crystals within a cell of an unidentified matrine vibrio, with parallelepipedal projections. (c) Bright-held STEM of tooth-shaped (anisotropic) magnetosomes from an unidentified marine rod-shaped bacterium. 
0

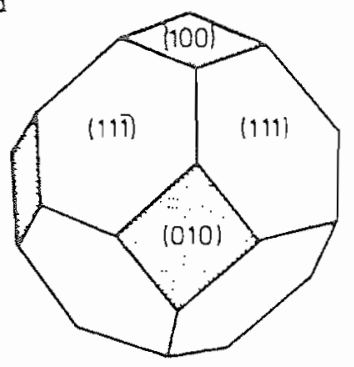

c

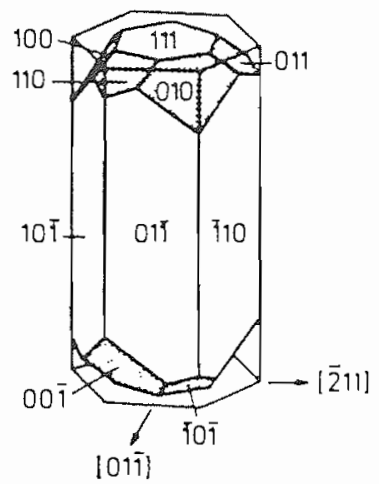

b

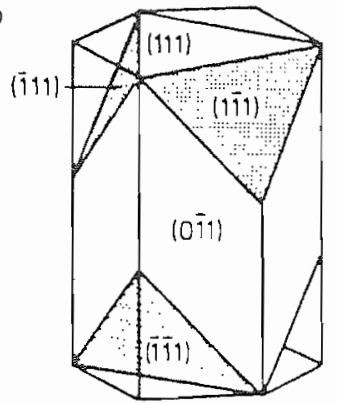

d

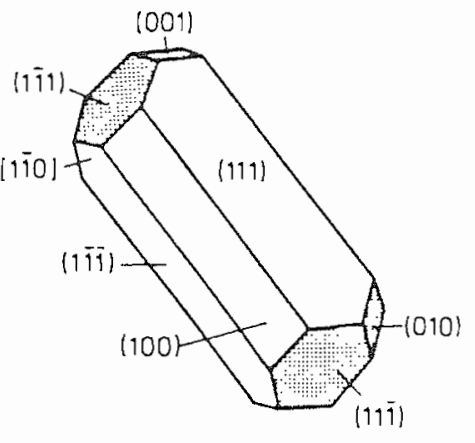

e

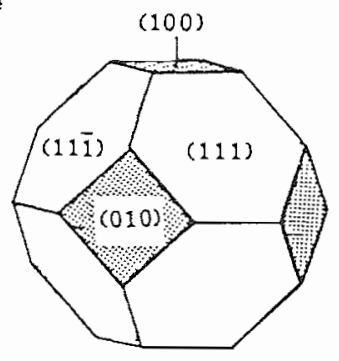

$f$

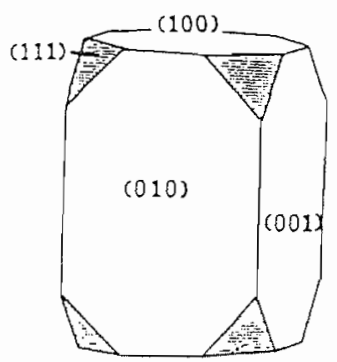

Figure 3. Idealized magnetite (a to d) and greigite (e and f) crystal morphologies derived from high-resolution TEM studies of magnetosomes from magnetotactic bacteria. (a and e) Cubo-octahedrons. (b, $c$, and f) Variations of pseudo-hexagonal prisms. (d) Elongated cubo-octahedron. Adapted from references 70 and 97.

This aspect of magnetosome particle morphology has been used to distinguish magnetosome magnetite from detrital or BIM-type magnetite using electron microscopy of magnetic extracts from sediments $(37,38,141,143,173-175)$.

Although all freshwater magnetotactic bacteria synthesize magnetite as the mineral phase of their magnetsomes, many marine, estuarine, and salt marsh species produce an iron sulfide-type magnetosome which consists primarily of the magnetic iron sulfide greigite $(7,8,11,69,70,104,145,146)$. Reports of iron pyrite (104) and pyrrhotite (48) have not been confirmed and may represent misidentifications 
of additional iron sulfide species occasionally observed with greigite in cells (145, 146) (discussed below). Currently recognized greigite-producing magnetotactic bacteria include a many-celled magnetotactic procaryote (MMP) that consists of an aggregation of about 20 to 30 cells arranged in a spherical manner, which is motile as an entire unit and not as separate cells $(40,49,150,151)$, and a variety of relatively large, rod-shaped bacteria $(7,8,11,69,70)$.

The iron sulfide-type magnetosomes contain either particles of greigite $(69,70)$ or a mixture of greigite and transient nonmagnetic iron sulfide phases that probably represent mineral precursors to greigite $(145,146)$. These phases include mackinawite and probably a sphalerite-type cubic FeS $(145,146)$. Based on TEM observations, electron diffraction, and known iron sulfide chemistry $(18,20,21)$, the reaction scheme for greigite formation in the magnetotactic bacteria appears to be cubic FeS $\rightarrow$ mackinawite (tetragonal $\mathrm{FeS}) \rightarrow$ greigite $\left(\mathrm{Fe}_{3} \mathrm{~S}_{4}\right)(145,146)$. The de novo synthesis of nonmagnetic crystalline iron sulfide precursors to greigite aligned along the magnetosome chain indicates that chain formation and the orientation of the magnetosomes in the chain do not necessarily involve magnetic interactions. Interestingly, under the strongly reducing, sulfidic conditions at neutral $\mathrm{pH}$ in which the greigite-producing magnetotactic bacteria are found $(7,8)$, greigite particles would be expected to transform into pyrite $(18,20)$. It is not known if and how cells prevent this transformation.

As with magnetite, three particle morphologies of greigite have been observed in magnetotactic bacteria: (i) cubo-octahedral (the equilibrium form of facecentered cubic greigite) $(69,70)$, (ii) pseudo-rectangular prismatic (Fig. 3e to $\mathrm{f}$ and 4) $(69,70)$, and (iii) tooth shaped $(145,146)$. Like that of their magnetite counterparts, the morphology of the greigite particles also appears to be species-and/ or strain specific, although confirmation of this observation will require controlled studies of pure cultures of greigite-producing magnetotactic bacteria, none of which
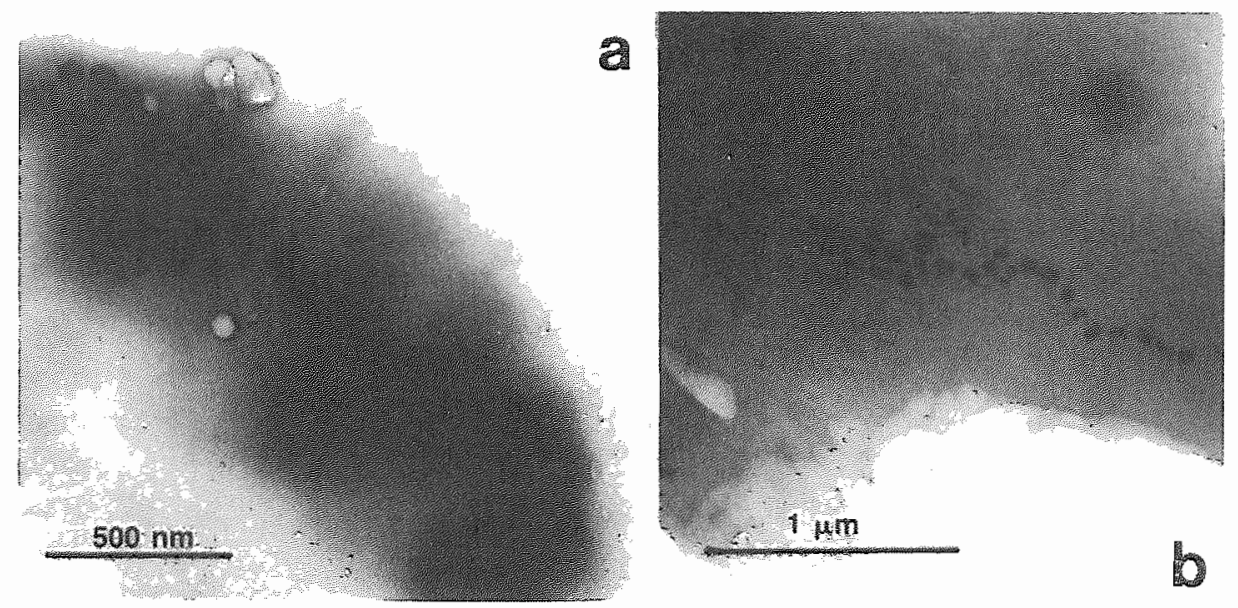

Figure 4. Morphologies of greigite $\left(\mathrm{Fe}_{3} \mathrm{~S}_{4}\right)$ particles within cells of unidentified rodshaped bacterial collected from the sulfidic waters of al salt marsh pool. (a) TEM of cubo-octahedra. (b) TEM of rectangular prisms. 
is currently available. One clear exception to this rule is the MMP (see above) (7, $8,11,49,104,150,151)$. This unusual microorganism, found in sait marsh pools all over the world and in some deep-sea sediments, contains pleomorphic, pseudo rectangular prismatic, tooth-shaped, and cubo-octahedral greigite particles. Some of the these particle morphologies are shown in Fig. 5. Therefore, the biomineralization process(es) appears to be more complicated in this organism than in the rods with greigite-containing magnetosomes or in magnetite-producing magnetotactic bacteria.

One slow-swimming, rod-shaped bacterium, collected from the OATZ from the Pettaquamscutt Estuary, was found to contain arrowhead-shaped crystals of magnetite and rectangular prismatic crystals of greigite co-organized within the same chains of magnetosomes (this organism usually contains two parallel chains of magnetosomes), as shown in Fig. $6(9,13)$. In cells of this uncultured organism, the magnetite and greigite crystals occur with different, mineral-specific morphologies and sizes and are positioned with their long axes oriented along the chain direction. Both particle morphologies have been found in organisms with singlemineral-component chains $(69,70,100,101)$, which suggests that the magnetosome membranes surrounding the magnetite and greigite particles contain different nucleation templates and that there are differences in magnetosome vesicle biosynthesis. Thus, it is likely that two separate sets of genes control the biomineralization of magnetite and greigite in this organism.

In sum, the consistent narrow size range (41) and morphologies of the magnetosome particles represent features typical of BCM and are clear indications that

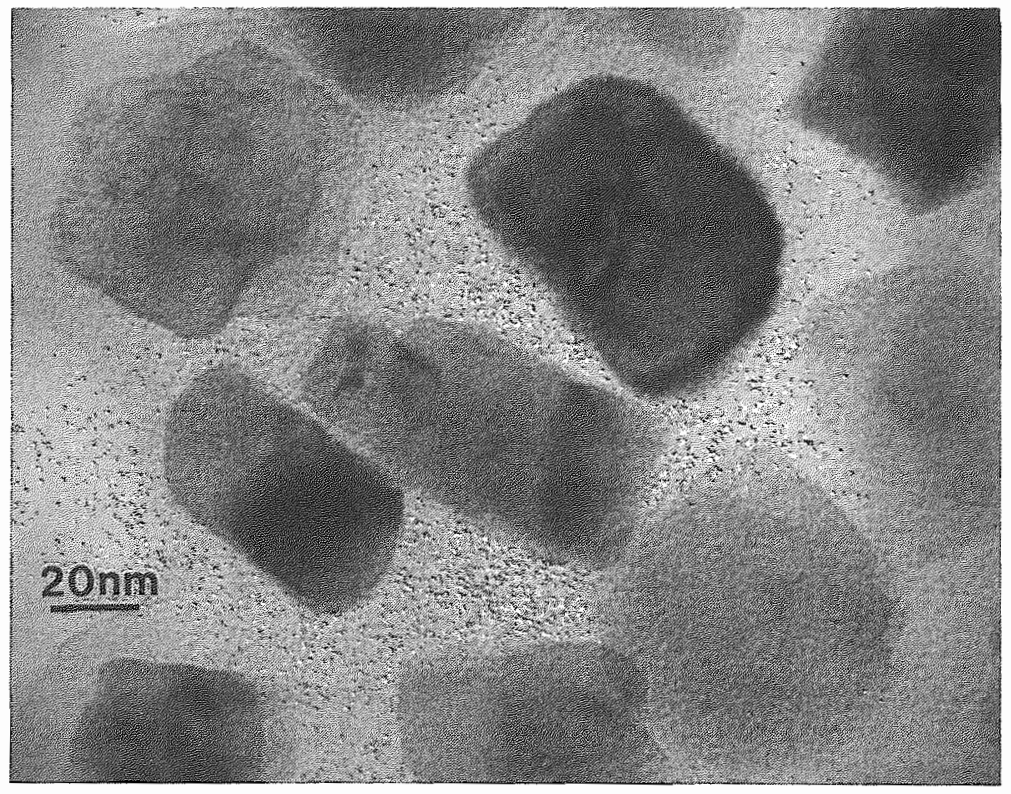

Figure 5. High-magnification bright-field STEM of pleomorphic greigitemackinawite particles within MMP cells. 


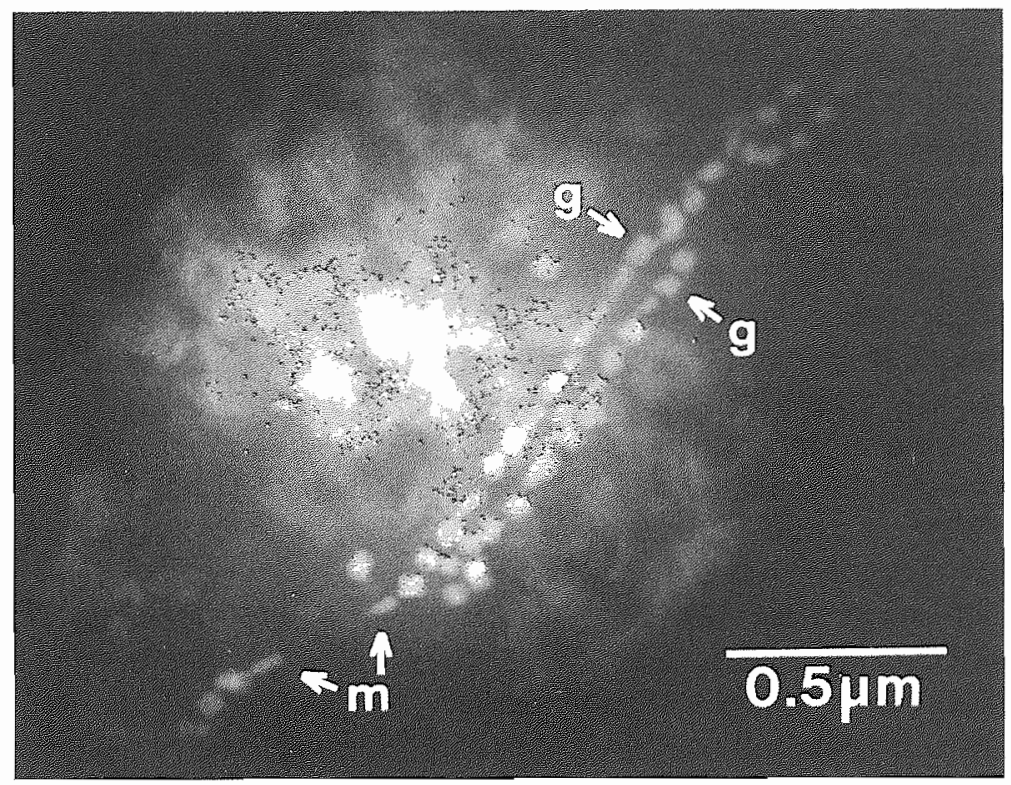

Figure 6. Dark-field STEM of rectangular prismatic greigite (g) and tooth-shaped magnetite particles $(\mathrm{m})$ co-organized within the same chains of magnelosomes in an unusual rod-shaped magnetotactic bacterium collected from the Petaquamscut Estuary (see the text).

the magnetotactic bacteria exert a high degree of control over the biomineralization processes involved in magnetosome synthesis.

\section{Effect of Environmental Conditions on Biomineralization}

Can local environmental conditions affect the biomineralization of the mineral phase of the magnetosome? This might occur in the form of variations in the stoichiometry of the metal and/or the nonmetal components of the mineral phase or through the replacement of the either the metal or nonmetal component of the magnetosome mineral phase. Here we discuss stoichiometry changes and specifically whether iron can be replaced with other transition metal ions and whether sulfur and oxygen can replace each other as the nonmetal component in the magnetosome mineral phase.

The replacement of iron in magnetosomes has not been studied in great detail in pure cultures. Gorby (62) showed that iron could not be replaced by other transition metal ions, including titanium, chromium, cobalt, copper, nickel, mercury, and lead, in the magnetite crystals of Magnetospirillum magnetotactic!n when cells were grown in the presence of these ions. However, Towe and Moench (183) reported very small amounts of titanium in the magnetite particles of an uncultured freshwater magnetotactic coccus collected from a wastewater treatment pond. Significant amounts of copper have been found in the greigite particles of the MMP (11) described above. The amount of copper was extremely variable and ranged from about 0.1 to 10 atomic\% relative to iron. The copper appeared to be concen- 
trated mostly on the surface of the particles and was present only in organisms collected from a salt marsh in Morro Bay, Calif,, and not in those collected from other sites. Interestingly, magnetosomes in rod-shaped magnetotactic bacteria that also produce greigite collected from the same site in Morro Bay did not contain copper. The presence of copper did not appear to affect the function of the magnetosomes, since the organisms were still magnetotactic. More recently, copper has also been found in the greigite particles of rod-shaped magnetotactic bacteria from sites other than Morro Bay (146). These observations may indicate that the mineral phase of the magnetosomes in these organisms is more susceptible to chemical and redox conditions in the external environment and/or that the magnetosomes could function in transition metal detoxification.

The conversion of cubic FeS and mackinawite to greigite $(145,146)$ in greigiteproducing magnetotactic bacteria clearly represents an example of changes in the stoichiometry of the metal and nonmetal components of the magnetosome particle. Based on thermodynamic considerations, cubic FeS and mackinawite transform to greigite under strongly reducing sulfidic conditions at neutral $\mathrm{pH}(21,145,146)$, conditions that exist where these organisms are found $(7,8)$. There is also the possibility that these transformations are catalyzed by the cell.

Cells of the slow-moving magnetotactic rod from the Pettaquamscutt Estuary that biomineralize both magnetite and greigite were found to extend well below the OATZ proper at this chemically stratified site (9). Cells collected from the more oxidized regions of the OATZ contained more or exclusively arrowhead-shaped magnetite particles, while cells collected from below the OATZ in the anaerobic sulfidic zone contained more or exclusively greigite particles. This finding suggests that environmental parameters such as local molecular oxygen and/or hydrogen sulfide concentrations and/or redox conditions somehow regulate the relative biomineralization of iron oxides and iron sulfides in this bacterium (9).

\section{Chemistry and Biochemistry of Magnetosome Formation}

The first step in the synthesis of magnetite (and probably greigite as well) in magnetotactic bacteria is the uptake of iron. Free reduced Fe(II) is very soluble (up to $100 \mathrm{mM}$ at neutral $\mathrm{pH}[132]$ ) and is easily taken up by bacteria, usualiy by nonspecific means. However, because free oxidized Fe(1II) is so insoluble, most microbes have to rely on iron chelators which bind and solubilize Fe(III) for uptake. Microbially produced Fe(III) chelators are called siderophores and are defined as low-molecular-mass $(<1 \mathrm{kDa})$, virtually specific ligands that facilitate the solubilization and transport of Fe(III) (67). Siderophores are generally produced under iron-limited conditions, and their synthesis is repressed under high-iron conditions. Several studies, all involving magnetotactic spirilla, have focused on iron uptake in the magnetotactic bacteria.

A hydroxamate siderophore was found to be produced by cells of $M$. magnetotacticum grown under high-iron but not under low-iron conditions (139). Thus, the siderophore production pattern here is the reverse of what is normally observed. Later studies have not confirmed this finding. Earlier, Frankel et al. (56) assumed that iron uptake by this organism probably occurred via a nonspecific transport system. Although iron is supplied as Fe(III) chelated to quinic acid, the growth 
medium also contains chemical reducing agents (e.g., thioglycolate or ascorbic acid) potent enough to reduce Fe(III) to Fe(II). Thus, both forms of iron are present in the growth medium, and it is not known which form is taken up by the cell.

Nakamura et al. (128) did not detect siderophore production by Magnetospirill.um strain AMB-1 and concluded that iron was taken up as Fe(III) by cells and that $\mathrm{Fe}(\mathrm{III})$ uptake was mediated by a periplasmic binding protein-dependent iron transport system. Schüler and Baeuerlein (156) found that spent medium stimulated iron uptake to a high degree in cells of $M$. gryphiswaldense but found no evidence for the presence of a siderophore. They also showed that the major portion of iron for magnetite synthesis was taken up as Fe(III) and that Fe(III) uptake appears to be an energy-dependent process. Fe(II) was also taken up by cells but by a slow, diffusion-like process, while Fe(III) uptake followed Michaelis-Menten kinetics

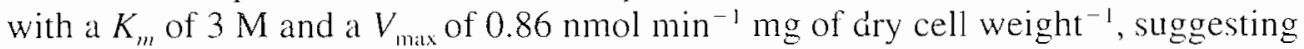
that Fe(III) uptake by cells of $M$. gryphiswaldense is a low-affinity but high-velocity transport system (156). In a later study (157) using the same organism, Schüler and Baeuerlein showed that magnetite formation was induced in nonmagnetotactic cells by a low threshold oxygen concentration of about 2 to $7 \mu \mathrm{M}$ (at $30^{\circ} \mathrm{C}$ ) and was tightly linked to Fe(III) uptake.

Few studies have addressed what occurs in the cell after iron is taken up by magnetotactic bacteria. Frankel et al. (56) examined the nature and distribution of major iron compounds in $M$. magnetotacticum by using ${ }^{57} \mathrm{Fe}$ Mössbauer spectroscopy. They proposed a model in which Fe(III) is taken up by the cell (by nonspecific means as described above) and reduced to $\mathrm{Fe}(\mathrm{II})$ as it enters the cell. It is then thought to be reoxidized to form a low-density hydrous Fe(III) oxide, which is then dehydrated to form a high-density Fe(III) oxide (ferrihydrite), which was directly observed in cells. In the last step, one-third of the Fe(III) ions in ferrihydrite are reduced and, with further dehydration, magnetite is produced. However, Schüler and Baeuerlein (157) showed that in cells of $M$. gryphiswaldense, Fe(III) is taken up and rapidly converted to magnetite without any apparent delay, suggesting that there is no significant accumulation of a precursor to magnetite inside the cell. at least under the conditions of the experiment, which appeared to be optimal for magnetite production by that organism.

The mechanism by which specific shapes of magnetite are formed is unknown at present, but it is thought that the final two steps occur in the magnetosome membrane vesicle, which apparently nucleates and also constrains crystal growth. It is clear that many more studies involving several different organisms are required before we fully understand the precipitation of magnetite and greigite in magnetotactic bacteria.

\section{Physiology}

Many features common to the magnetotactic bacteria were described above. There are also some physiological features common to all that have been studied. However, since only a handful of strains are in pure culture and most of these are microaerophilic freshwater spirilla that produce cubo-octahedral particles of magnetite, the amount of data is limited. Although magnetite synthesis has not yet been linked to the physiology of a magnetotactic bacterium, it is important to understand 
the physiology of these bacteria and the conditions under which they synthesize magnetosomes in order to find this link. One point is clear, though; magnetite is formed by physiologically diverse magnetotactic bacteria only under microaerobic and/or anaerobic conditions, depending on the species.

The first magnetotactic bacterium to be isolated and grown in pure culture was Magnetospirillum (formerly Aquaspirillum [155]) magnetotacticum strain MS-1 $(31,106)$. This obligately microaerophilic species represents the most extensively studied magnetotactic bacterium. It was isolated from a freshwater swamp and synthesizes cubo-octahedral crystals of magnetite $(97,98)$. Its cells are helical and possess an unsheathed polar flagellum at each end. This organism is obligately respiratory and cannot ferment and is nutritionally a chemoorganoheterotroph that uses organic acids as a source of energy and carbon (31). The cells do not produce catalase, which might explain their microaerophilic nature, but they produce several periplasmic superoxide dismutases of the iron and manganese types (161). Cells fix atmospheric dinitrogen, as evidenced by their ability to reduce acetylene 10 ethylene under nitrogen-limited conditions $(5,6 \mathrm{a})$. This organism uses oxygen or nitrate as a terminal electron acceptor and is a denitrifier that produces nitrous oxide and dinitrogen from nitrate (6). Unlike most denitrifying bacteria, cells require a small amount of molecular dioxygen for nitrate-dependent growth (6). Interestingly, cells produce more magnetite when grown with nitrate than with oxygen as a terminal electron acceptor. However, molecular oxygen must still be present for magnetite synthesis when nitrate is present in the growth medium, with the optimal concentration for maximum magnetite yields being $1 \%$ oxygen in the headspace of cultures and concentrations greater than $5 \%$ being inhibitory (32). Recent isotope experiments clearly show that molecular $\mathrm{O}_{2}$ is not incorporated into magnetite, however, and that the oxygen in magnetite is derived from water (95). The role that molecular $\mathrm{O}_{2}$ plays in magnetite synthesis is thus unknown, but it has been clearly shown to affect the synthesis of specific proteins in $M$. magnetotacticum. For example, Sakaguchi et al. (154) showed that the presence of oxygen in nitrate-grown cultures repressed the synthesis of a $140-\mathrm{kDa}$ membrane protein in M. magnetotacticum whose function is unknown and Short and Blakemore (161) showed that increasing the oxygen tension from 1 to $10 \%$ of saturation in cultures of $M$. magnetotacticum caused cells to express increased activity of the manganesetype superoxide dismutase relative to that of the iron type.

Guerin and Blakemore (66) reported anaerobic, iron-dependent growth of $M$. magnetotacticum in the absence of nitrate. Although cells grown with "amorphous" Fe(III) were extremely magnetic and produced nearly twice as many magnetosomes as did nitrate-grown cells with optimal $\left[\mathrm{O}_{2}\right](32)$, they grew very slowly under these conditions and the growth yields were poor compared to those on nitrate and/ or oxygen. These authors further showed that iron oxidation may also be linked to aerobic respiratory processes, energy conservation, and magnetite synthesis in $M$. magnetotacticum. However, given that cells produce so much magnetite during growth with Fe(III) under anaerobic conditions, it would appear that aerobic iron oxidation is not necessary for magnetite synthesis.

In an effort to understand the relationship between nitrate and oxygen utilization and magnetite synthesis, Fukumori and coworkers examined electron transport and 
cytochromes in $M$. magnetotacticum. Tamegai et al. (179) reported a novel "cytochrome $a_{1}$-like" hemoprotein that was present in greater amounts in magnetic cells than nonmagnetic cells. They did not find any true cytochrome $a_{1}$ or any $o^{-}$ type cytochromes, which were once considered to be terminal oxidases in $M$. magnetotacticum by others (135). A new ccb-type cytochrome c oxidase (178) and a cytochrome $c d_{1}$-type nitrite reductase (195) were isolated and purified from $M$. magnetotacticum. The latter protein was of particular interest since it showed Fe(II): nitrite oxidoreductase activity, which may be linked to the oxidation of $\mathrm{Fe}$ (II) in the cell and thus to magnetite synthesis (195).

Cells of $M$. magnetotacticum actively reduce Fe(III) (28) and translocate protons when $\mathrm{Fe}$ (III) is introduced into them anaerobically (160), suggesting that cells conserve energy during the reduction of Fe(III). Growth yields on Fe(III) suggest that iron reduction is also linked to growth, as in the dissimilatory iron-reducing bacteria (66). Fe(III) reductase activity has also been demonstrated in cell extracts of M. magnetotacticum (140), and recently, Noguchi et al. (133) purified a Fe(III) reductase from this microorganism. The enzyme appears to be loosely bound on the cytoplasmic face of the cytoplasmic membrane, has an apparent molecular mass of $36 \mathrm{kDa}$, and requires reduced NADH and flavin mononucleotide as an electron donor and cofactor, respectively. Enzyme activity was inhibited by zinc, which also reduced the number of magnetite-containing magnetosomes when included in the growth medium as $\mathrm{ZnSO}_{4}$.

Other microaerophilic magnetotactic spirilla, physically identical to $M$. magnetotacticum, have been isolated in recent years. Cells of Magnetospirillum strain AMB-1, isolated by Matsunaga et al. (113), are apparently much more oxygen tolerant than are those of other magnetotactic species and, unlike other magnetotactic bacteria, can form colonies on the surface of agar plates under a fully aerobic atmosphere. This species seems very similar to $M$. magnetotacticum in that it appears to synthesize cubo-octahedral crystals of magnetite, is obligately respiratory, and has a chemoorganoheterotrophic mode of nutrition using organic acids as sources of energy and carbon. 1ts cells, like those of $M$. magnetotacticum, form more magnetosomes when grown with nitrate, but unlike cells of $M$. magnetotacticum, they grow anaerobically with nitrate and synthesize magnetite without molecular oxygen (113). Growth and inhibitor studies $(113,115)$ show that Magnetospirillum strain AMB-1 uses nitrate as a terminal electron acceptor, although the products of nitrate reduction were not reported. Cells of another microaerophilic, freshwater magnetotactic spirillum, described by Schleifer et al. (155), $M$. gryphiswaldense, are very similar in morphology, ultrastructure, and physiology to the other Magnetospirillum species described above and, like cells of all the freshwater magnetotactic spirilla, produce cubo-octahedral crystals of magnetite. As in $M$. magnetotacticum, magnetite production in $M$. gryphiswaldense is induced under microaerobic conditions $(156,157)$. Whether $M$. gryphiswaldense uses nitrate as a terminal electron acceptor and grows anaerobically with it or any other terminal electron acceptor or whether nitrate affects magnetite synthesis in this bacterium, as it does in $M$. magnetotacticum, was not reported. Like cells of $M$. magnetotacticum, those of both $M$. gryphiswaldense and Magnetospirillum strain AMB-1 appear to fix atmospheric dinitrogen (6a). 
A marine magnetotactic vibrioid bacterium, strain $\mathrm{MV}-1$, was isolated by $\mathrm{Ba}-$ zylinski et al. (10). Cells of strain MV-1 possess a single, unsheathed polar flagellum and grow and synthesize pseudo-hexahedral prismatic crystals of magnetite in their magnetosomes microaerobically and anaerobically with nitrous oxide as the terminal electron acceptor. The cells appear to produce more magnetite under anaerobic than under microaerobic conditions (10). This species is nutritionally versatile, being able to grow chemoorganoheterotrophically with organic and amino acids as carbon and energy sources and chemolithoautotrophically with thiosulfate or sulfide as energy sources (oxidizing them to sulfate) and carbon dioxide as the sole carbon source (L. K. Kimble and D. A. Bazylinski, Abstr. 96th Gen. Meet. Am. Soc. Microbiol. 1996, abstr. K-174, 1996). Cells produce intracellular sulfur deposits when grown with sulfide (Kimble and Bazylinski, Abstr. 96th Gen. Meet. Am. Soc. Microbiol. 1996). As do virtually all aerobic chemolithoautotrophic bacteria, strain MV-1 uses the Calvin-Benson cycle for autotrophic carbon dioxide fixation (116). Cell extracts from thiosulfate-grown cells of strain MV-1 show ribulose bisphosphate carboxylase/oxygenase (Rubisco) activity (Kimble and Bazylinski, Abstr. 96th Gen. Meet. Am. Soc. Microbiol. 1996), and recently Dean and Bazylinski (A. J. Dean and D. A. Bazylinski, Abstr. 96th Gen. Meet. Am. Soc. Microbiol. 1996, abstr. H-207, p. 369, 1996) cloned and sequenced a cbbM gene (which encodes form II Rubisco enzymes) from strain MV-1. They found no evidence for a $c b b L$ gene (which encodes form I Rubisco enzymes) in Southern analyses despite using $c b b L$ gene probes from several different organisms. Because many uncultured magnetotactic bacteria collected from natural habitats thrive in oxygen-sulfide inverse gradients and contain internal sulfur deposits $(9,51,71$, 120,168 ), it seems likely that many species are chemolithoautotrophs that derive electrons from the oxidation of sulfide.

By using pulsed-field gel electrophoresis, the genome of strain MV-] was found to consist of a single, circular chromosome of approximately $3.7 \mathrm{Mb}$ (39). There was no evidence of linear chromosomes or extrachromosomal DNA such as plasmids.

A virtually identical strain to strain MV-1, designated MV-2, was isolated from the Pettaquamscutt Estuary $(40,118)$. Cells of this strain produce the same morphological type of magnetite crystals as do cells of strain MV-l (118) and display many of the same phenotypic traits as do cells of strain $\mathrm{MV}-1$, such as anaerobic growth with nitrous oxide as a terminal electron acceptor, heterotrophic growth with organic and amino acids, and chemolithoautotrophic growth on reduced sulfur compounds. However, strain MV-2 shows slightly different restriction fragment patterns in pulsed-field gels from those of strain $\mathrm{MV}-1$ with the same restriction enzymes (39). As with strain MV-1, the genome of strain MV-2 consists of a single circular chromosome of a similar size, about $3.6 \mathrm{Mb}$ (39).

Strain RS-1 is a gram-negative, sulfate-reducing, rod-shaped bacterium that grows and produces bullet-shaped particles of magnetite only under anaerobic conditions (153). Its cells are helicoid to rod shaped and possess a single polar flagellum. Little is known about the physiology of this strain. Cells grow chemoorganoheterotrophically using certain organic acids and alcohols as carbon and energy sources and cannot use nitrate as a terminal electron acceptor. 
Several other pure cultures of magnetotactic bacteria exist, but they appear to be obligate microaerophiles and grow poorly (Bazylinski, unpublished). Hence, very little is known about them. Strain MC-1, a marine coccus, produces pseudo hexahedral prisms of magnetite and grows chemolithoautotrophically with thiosulfate or sulfide as an electron and energy source $(40,52,119)$. It has a genome size of approximately $4.5 \mathrm{Mb}$ as determined by pulsed-field gel electrophoresis (39). Strain MV-4, a small marine spirillum, produces elongated octahedrons of magnetite and can grow chemolithoautotrophically with thiosulfate or chemoorganoheterotrophically with succinate (118).

\section{Magnetosome Membrane and BCM of Magnetite}

In all the magnetite-producing magnetotactic bacteria examined to date, the magnetosome crystals appear to be encased in a coating or membrane. In $M$. magnetotacticum, this structure, the so-called magnetosome membrane, consists of a lipid bilayer containing phospholipids and numerous proteins, some of which appear to be unique to this membrane and are not found in the outer or cell membrane (63). The magnetosome membrane does not appear to be contiguous with the cell membrane and is presumably the locus of control over the size and morphology of the inorganic particle as well as the structural entity that anchors the magnetosome at a particular location within the cell. However, it is not known whether the magnetosome membrane is premade as an empty membrane vesicle prior to the biomineralization of the mineral phase. Empty and partially filled vesicles have been observed in iron-starved cells of $M$. magnetotacticum (63) but have not been commonly observed in other magnetotactic strains. The unlikely alternative would be that nucleation of the mineral phase occurs before it is surrounded by the membrane. In any case, most biochemical and molecular biological studies directed toward the understanding of the biomineralization processes involved in magnetosome formation are focused on aspects of the magnetosome membrane, particularly on the functions of specific proteins present on this membrane.

The magnetosome membrane appears to be a universal feature of at least the magnetite-producing species of magnetotactic bacteria, since it has been found in virtually all cultured and some noncultured strains (Fig. 7). Although it is not known whether greigite-producing magnetotactic bacteria actually have a magnetosome membrane like their magnetite-producing counterparts, it seems likely that they do, based on the consistent particle morphologies observed in these bacteria.

\section{Molecular Biology of Magnetosome Formation and Genetics of Magnetotactic Bacteria}

It is not known how many genes are required for magnetosome synthesis, how these genes are regulated, etc. Establishing a genetic system with the magnetotactic bacteria is an absolute necessity before these questions can be answered and although several laboratories (including ours) have persisted in trying to achieve this goal, they have been hampered by many problems including the lack of a significant number of magnetotactic bacterial strains, the fastidiousness of the organisms in culture and the elaborate techniques required for the growth of these organisms, and the inability of almost all these strains to grow on the surface of agar plates in experiments to screen for mutants etc. While the researchers involved have taken 


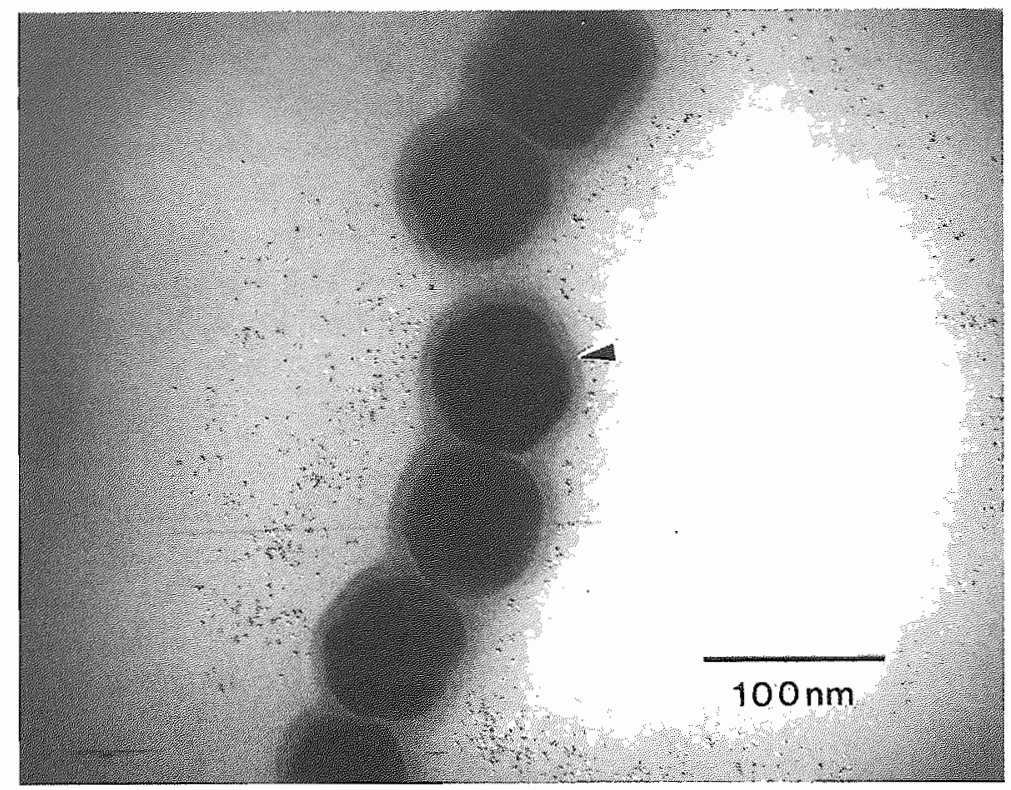

Figure 7. Dark-field STEM of pseudo-hexagona! prismatic magnetite particles from the marine magnetotactic coccus strain MC-1, surrounded by the manetosome membrane (arrowhead).

different approaches, most of the genetic and molecular studies have involved one or more of the magnetotactic spirilla.

Waleh and coworkers $(23,190)$ initiated the first studies in the establishment of a genetic system with magnetotactic bacteria in order to understand the molecular biology of magnetosome synthesis in these microorganisms. Working with $M$. magnetotacticum strain MS-1, they showed that at least some of the genes of this organism can be functionally expressed in E. coli and that the transcriptional and translational elements of the two microorganisms are compatible (necessary features for a good genetic system). They were able to clone, characterize, and sequence the recA gene from $M$. magnetotacticum $(23,24)$. They later examined iron uptake by $M$. magnetotacticum. They cloned and characterized a 2 -kb DNA fragment from $M$. magnetotacticum that complemented the aroD (biosynthetic dehydroquinase) gene function in E. coli and Salmonella enterica serovar Typhimurium. aro $D$ mutants of these strains cannot take up iron from the growth medium. In other words, when the 2-kb DNA fragment from $M$. magnetotacticum was introduced into these mutants, the ability of the mutants to take up iron from the growth medium was restored (22), suggesting that the 2-kb DNA fragment may be important in iron uptake (and therefore possibly in magnetite synthesis) in $M$. magnetotacticum. Although the cloned fragment restored iron uptake deficiencies in siderophoreless, iron uptake-deficient mutants of $E$. coli, it did not mediate siderophore biosynthesis (22). 
As mentioned above, cells of Magnetospirillum strain AMB-1 (113) are apparently much more oxygen tolerant than are those of other magnetotactic species and form colonies on the surface of agar plates under air. Colonies on plates incubated under fully aerobic conditions (21\% oxygen) were white and contained cells that were nonmagnetic. However, when the oxygen concentration of the incubation atmosphere was decreased to $2 \%$, the cells formed black-brown colonies that were made up of magnetic cells. This feature facilitated the selection of nonmagnetic mutants of Magnetospirillum strain AMB-1, obtained by the introduction of transposon Tn5 into the genome of Magnetospirillum AMB-1 by the conjugal transfer of plasmid pSUP102l which contained the transposon (112). This plasmid and its transposon was also introduced into $M$. magnetotacticum, but this strain did not form colonies. Using Tn5-derived nonmagnetic mutants of Magnetospirillum strain AMB-1, Nakamura et al. (126) found that at least three regions of the Magnetospirillum strain AMB-1 chromosome were required for the successful synthesis of magnetosomes. One of these regions, $2,975 \mathrm{bp}$ in length, contained two putative open reading frames. One of these, designated magA, encoded a protein that is homologous to two cation efflux proteins, the E. coli potassium ion-translocating protein, KefC, and the putative sodium ion/proton antiporter, NapA, from Enterococcus hirae. magA was expressed in $E$. coli, and membrane vesicles prepared from these cells that contained the $m a g A$ gene product took up iron only when ATP was supplied, indicating that energy was required for the uptake of iron. The same group, using a magA-luc fusion protein, showed that the MagA protein is a membrane protein that is localized in the cell membrane and perhaps the magnetosome membrane as well (127). Interestingly, the magA gene appears to be expressed to a much greater degree when wild-type Magnetospirillum strain AMB-1 cells are grown under iron-limited conditions rather than iron-sufficient conditions. in which they would produce more magnetosomes. Moreover, the nonmagnetotactic Tn5 mutant overexpressed the magA gene under iron-limited conditions, although it did not make magnetosomes. Thus, although some evidence suggests that the MagA protein is involved in iron transport, the role of the magA gene in magnetosome synthesis, if there is one, is unclear.

Okuda el al. (136) took a different "reverse genetics" approach to the magnetosome problem. They found three proteins, with apparent molecular masses of 12 . 22 , and $28 \mathrm{kDa}$, that appear to be unique to the magnetosome membranes of $M$. magnetotacticum and are not present in the cellular membrane fraction. They were able to determine enough of the $\mathrm{N}$-terminal amino acid sequence of the 22-kDa protein to construct a 17 -bp oligonucleotide probe for the genomic cloning of the gene encoding that protein. They also found that the protein exhibited significant homology to a number of proteins that belong to the tetratricopeptide repeat protein family, which include mitochondrial protein import receptors and peroxisomal protein import receptors. Thus, although the role of the $22-\mathrm{kDa}$ magnetosome membrane protein in magnetosome synthesis has not been elucidated, it may function as a receptor interacting with associated cytoplasmic proteins (136).

Cells of the marine vibrio strain MV-1, like those of $M$. magnetotacticum, also produce a number of magnetosome membrane proteins that are not found in any other cellular fractions (B. L. Dubbels and D. A. Bazylinski. Abstr. 98th Gen. Meet. 
Am. Soc. Microbiol. 1998, abstr. H-82, p. 290, 1998) (Fig. 8). N-terminal sequences have been reported (Dubbels and Bazylinski, Abstr. 98th Gen. Meet. Am. Soc. Microbiol. 1998) for at least three of these proteins, but the use of degenerate primers based on these sequences to clone the genes responsible for encoding these proteins has so far proved unsuccessful.

A stable, spontaneous, nonmagnetotactic mutant of strain MV-1 that does not synthesize magnetosomes has been isolated and partially characterized (Dubbels and Bazylinski, Abstr. 98th Gen. Meet. Am. Soc. Microbiol. 1998). Protein profiles of the different cell fractions of wild-type MV-1 and the mutant were compared. Cells of the mutant strain do not produce the magnetosome membrane proteins or

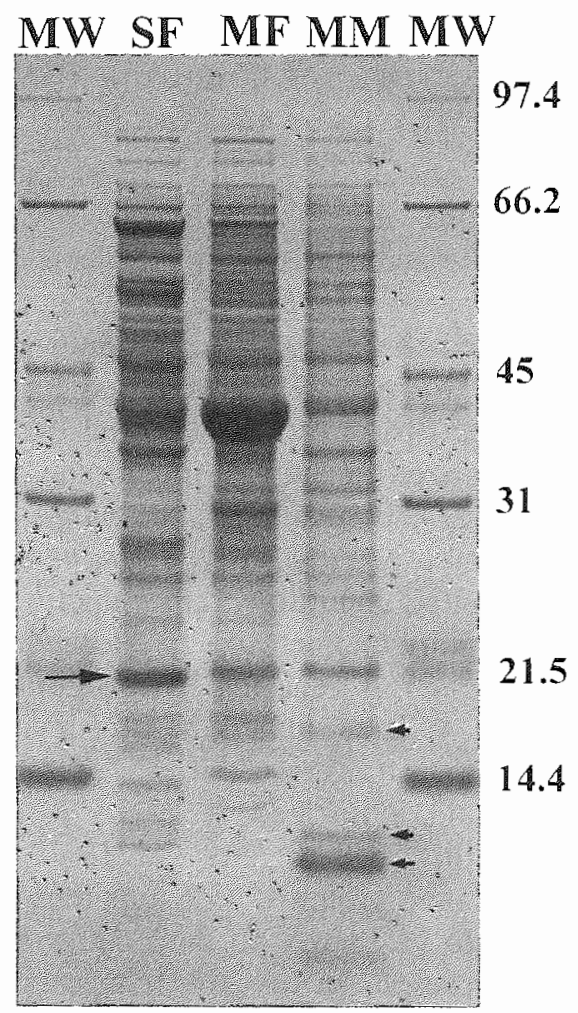

Figure 8. Sodium dodecyl sulfate-polyacrylamide gel electrophoresis of wild-type strain MV-1 cell fractions. Cell fractions were separated by differential ultracentrifugation. Lanes: SF, soluble fraction; MF, membrane fraction (excluding magnetosome membranes); MM, magnetosome membranes; MW, molecular mass standards, with masses in kilodaltons shown on the right. Magnetosomes were purified as previously described (12), and magnetosome membranes were extracted from magnetosomes with $1 \%$ sodium dodecyl sulfate in $20 \mathrm{mM}$ HEPES (pH 7.2) (Dubbels and Bazylinski, Abstr. 98th Gen. Meet. Am. Soc. Microbiol. 1998). The large arrow denotes a soluble $19-\mathrm{kD}$ a protein that is not produced by a nonmagnetotactic mutant of strain MV-1 (see the text), and the small arrows denote some proteins that appear to be associated with the magnetosome membrane but not with the other cell fractions. 
a periplasmic 19-kDa protein produced in abundance by wild-type cells (Fig. 8). Degenerate primers, constructed from N-terminal sequence of this protein and conserved sequences from homologous proteins, were used to generate a 255-bp PCR product that was used to probe a genomic cosmid library of strain MV-1. The encoding the 19-kDa protein was cloned and sequenced (B. L. Dubbels and D. A. Bazylinski, Abstr. 99th Gen. Meet. Am. Soc. Microbiol. 1999, abstr. H-219, p. 371, 1999). A similar 19-kDa periplasmic protein was purified from Campylobacter jejuni (73). The protein is acidic, with an isoelectric point of 4.8 , and is iron regulated through the Fur (ferric uptake regulator) protein, its synthesis is repressed by high iron concentrations in the growth medium $(73,184)$. Interestingly, synthesis of the 19-kDa protein from strain MV-l also appears to be regulated by iron (Dubbels and Bazylinski, Abstr. 99th Gen. Meet. Am. Soc. Microbiol. 1999). The function of this protein in either microorganism is unknown, but similar proteins and genes encoding similar proteins have been found in several gram-negative pathogens including Treponema pallidum (177).

\section{Applications of Magnetotactic Bacteria, Magnetosomes, and Magnetic Particles}

Magnetotactic bacteria and their magnetic inclusions have novel magnetic properties. Some of these are discussed above, and others are described in more detail in various references (see, e.g.. references 14, 123, and 124). Because of these properties, magnetotactic bacterial cells and their magnetic crystals have been exploited in several scientific and commercial applications (109). For example, northseeking magnetotactic bacteria have been used to determine south magnetic poles in meteorites and rocks containing fine-grained $(<1,000 \mathrm{~nm})$ magnetic minerals $(59,60)$. They have also been used in magnetic cell separations after introducing magnetotactic bacteria into granulocytes and monocytes by phagocytosis (110).

Magnetotactic bacterial magnetite particles have been used in studies of magnetic domain analysis (61). The crystals have been used in many commercial applications including the immobilization of enzymes including glucose oxidase and uricase (11 ), the formation of magnetic antibodies in various fluoroimmunoassays (114) involving the detection of allergens (131) and squamous cell carcinoma cells (109) and the quantification of immunoglobulin G (130), the detection and removal of bacterial cells $(E$. coli) with a fluorescein isothiocyanate-conjugated monoclonal antibody immobilized on magnetotactic bacterial magnetite particles (129), and the transfer of genes into cells, a technology in which magnetosomes are coated with DNA and injected or "shot" (using a particle gun) into cells that are difficult to transform using more standard methods (109).

Considering that the bacterial magnetosome and its magnetic properties have been refined and optimized in the course of evolution by the cells that synthesize them by controlling the chemical composition, size, and morphology of the magnetic particles as well as their position within the cell, the elucidation of how magnetosomes form within the cell will yield clues to the production of ordered arrays of inorganic electronic, optical, and magnetic materials at the nanometer 
scale that could prove useful in many additional scientific and commercial applications.

\section{Magnetosomes as Evidence of Ancient Life on Mars}

As noted in the introduction, a number of mineralogical and other features from the Martian meteorite ALH84001 were suggested to result from biological processes on ancient Mars (117). Included in these features was the presence of ultrafine-grained magnetite, pyrrhotite, and possibly greigite. The magnetite crystals ranged from about 10 to $100 \mathrm{~nm}$, were in the superparamagnetic $(<35 \mathrm{~nm})$ and single-magnetic-domain size ranges, and were cuboid, teardrop, and irregular in shape. The iron sulfide particles varied in size and shape, with the pyrrhotite particles ranging up to $100 \mathrm{~nm}$. Both mineral particles were embedded in a fine-grained carbonate matrix on the rim of carbonate inclusions within the meteorite.

The magnetite particles, in particular, were invoked as evidence of life because of the similarities in size and morphology between these particles and those produced by the magnetotactic bacteria on Earth. In addition, the magnetite particles in ALH84001 differ greatly from those found in other meteorites. Other nanocrystalline forms of magnetite, including platelets and whiskers, are also present in ALH84001 (33). Some of these contain specific crystalline defects such as axial screw dislocations indicating that they were formed nonbiologically at high temperature by vapor phase growth (33). Although one study shows that statistical analysis of the sizes and shapes of of fine-grained magnetite crystals might prove to be a robust criterion for distinguishing between biogenic and nonbiogenic magnetite (41), the findings described above illustrate the need for additional criteria by which to distinguish between biogenic and nonbiogenic particles of iron minerals. One of these criteria might be whether magnetotactic bacteria isotopically fractionate iron and/or oxygen in the magnetite crystals they produce. In a recent study, Mandernack et al. (95) showed an oxygen isotopic fractionation that was temperature dependent and closely matched that for magnetite produced by a bacterial consortium containing thermophilic iron-reducing bacteria (197). Because these results contrast with those for magnetite thought to be formed inorganically, bacteria may fractionate oxygen in magnetite differently from what occurs in magnetite formed abiotically, which, in turn, might reflect different redox pathways of magnetite formation. No detectable fractionation in iron isotopes was observed in magnetite produced by $M$. magnetotacticum and strain MV-1. However, Beard et al. (14a) measured low ${ }^{56} \mathrm{Fe}$ values in the soluble ferrous iron produced by dissimilatory iron-reducing bacteria growing with the iron oxide mineral ferrihydrite, meaning that cells prefer to reduce the lighter, rarer ${ }^{54} \mathrm{Fe}$ (rather than ${ }^{56} \mathrm{Fe}$ ). How this isotopic fractionation is reflected in magnetite formed by iron-reducing bacteria remains to be seen. There is no doubt that discussion and debate on the interpretation of these fascinating findings will continue. It is nonetheless intriguing to think that microbes may be or have been responsible for the geochemical cycling of iron on other planets as well as on Earth. 


\section{CONCLUSIONS}

Magnetic effects have been reported in a large number of organisms other than bacteria, including invertebrates such as protists (182), honeybees (191), and mollusks (83) and vertebrates such as fish (192), amphibians (144), reptiles (82), birds (188, 189), and mammals (193) including humans $(76,77)$. Magnetite crystals virtually morphologically indistinguishable from those produced by the magnetotactic bacteria have been found in a euglenoid protist (182), in the ethmoid tissues of tuna and salmon and other animals $(165)$, and in the human brain $(76,77)$. In addition, other animals such as honeybees $(65,80)$ and pigeons (188) appear to contain particles of magnetite or hydrous iron oxides that could be precursors to magnetite. The fact that many higher creatures biomineralize single-magneticdomain magnetite crystals of similar morphologies suggests the intriguing idea that all these organisms have the same or a similar set of genes responsible for magnetite biomineralization that would probably have originated in the magnetotactic bacteria. Thus, studying how magnetotactic bacteria biomineralize magnetite might have a scientific impact far beyond the studies of microbiology and geology.

Acknowledgments. This chapter is dedicated to the memory of a most distinguished microbiologist. Holger W. Jannasch, who had a significant influence on the study of the magnetotactic bacteria.

We thank our many collaborators over the years for their participation in much of the work described herein. We particularly appreciate the efforts of graduate students A. J. Dean and B. L. Dubbels; our most recent associations with T. J. Beveridge, P. R. Buseck, J. D. Coates, R. Guerrero, B. L. Hoyle. K. Mandernack, D. S. McKay, M. Pósfai, and D. Schïler, K. L. Thomas-Keprta; and our continued coliaborations with D. R. Lovley and B. M. Moskowitz.

We acknowledge support from the U.S. Office of Naval Research (grant ONR NO(0014-91-J-1290), the U.S. National Science Foundation (grant CHE-97/4101), and the NASA Johnson Space Center (grant NAG 9.1115$)$.

\section{REFERENCES}

I. Akai, J., S. Takaharu, and S. Okusa. 1991. TEM study on biogenic magnetite in deep-sea sediments from the Japan Sea and the western Pacific Ocean. I. Electron Microsi. 40:110-117.

2. Balkwill, D. L., D. Maratea, and R. P. Blakemore. 1980. Ultrastructure of a magnetic spirillum 1. Bacteriol. 141:1399-1408.

3. Bazylinski, D. A. 1995. Structure and function of the bacterial magnetosome. ASM Netu: 61:337343.

4. Bazylinski, D. A. 1999. Synthesis of the bacterial magnetosome: the making of a nugnetic personality. Ini. Microbiol. 2:71-80.

5. Bazylinski, D. A., and R. P. Blakemore. 1983. Nitrogen tixation (alcetylene reduction) in Aquaspirilhum magnewatucum. Curr. Microbiol. 9:305-308.

6. Bazylinski, D. A., and R. P. Blakemore. 1983. Denitritication and assimilatory nitrate reduction in Acpuaspirillum magnetotacticum. Appl. Emirom. Microbiol. 46:1118-1124.

Ga. Bazylinski, D. A., A. J. Dean, D. Schüler, E. J. P. Phillips, and D. R. Lovley. N.-dependent growth and nitrogenase activity in the metal-metabolizing bacteria. Geobacter and Mognetospirillum species. Environ. Microbiol. in press.

7. Bazylinski, D. A., and R. B. Frankel. 1992. Produetion of iron sulfide minerals by magnetolactic bacteria from sulfidic environments, p. 147-159. In H. C. W. Skinner and R. W. Fitzparrick (ed.). Biomineralization Processes of Lron and Manganese: Modem and Ancient Environments. Calenat Verlag. Cremlingen-Destedt, Germany. 
8. Bazylinski, D. A., R. B. Frankel, A. J. Garratt-Reed, and S. Mann. 1990. Biomineralization of iron sulfides in magnetotactic bacteria from sulfidic environnents, p. 239-255. In R. B. Frankel and R. P. Blakemore (ed.), Iron Biominerals. Plenum Press, New York, N.Y.

9. Bazylinski, D. A., R. B. Frankel, B. R. Heywood, S. Mann, J. W. King, P. L. Donaghay, and A. K. Hanson. 1995. Controlled biomineralization of magnetite $\left(\mathrm{Fe}_{3} \mathrm{O}_{4}\right)$ and greigite $\left(\mathrm{Fe}_{3} \mathrm{~S}_{4}\right)$ in a magnetotactic bacterium. Appl. Environ. Microbiol. 61:3232-3239.

10. Bazylinski, D. A., R. B. Frankel, and H. W. Jannasch. 1988. Anaerobic production of nagnetite by a marine magnetotactic bacterium. Nature (London) 334:518-519.

11. Bazylinski, D. A., A. J. Garratt-Reed, A. Abedi, and R. B. Frankel. 1993. Copper association with iron sulfide magnetosomes in a magnetotactic bacterium. Arch. Microbiol. 160:35-42.

12. Bazylinski, D. A., A. J. Garratt-Reed, and R. B. Frankel. 1994. Electron microscopic studies of magnetosomes in magnetotactic bacteria. Microsc. Res. Tech. 27:389-401.

13. Bazylinski, D. A., B. R. Heywood, S. Mann, R. B. Frankel. 1993. $\mathrm{Fe}_{3} \mathrm{O}_{+}$and $\mathrm{Fe}_{3} \mathrm{~S}_{4}$ in a bacterium. Nature (London) 366:218.

14. Bazylinski, D. A., and B. M. Moscowitz. 1997. Microbial bionineralization of magnetic iron minerals: microbiology, magnetism and environmental significance. Rev. Mineral. 35:181-223,

14a.Beard, B. L., C. M. Johnson, L. Cox, H. Sun, K. H. Nealson, and C. Aguilar. 1999. lron isotope biosignatures. Science 285:1889-1892.

15. Bell, P. E., A. L. Mills, and J. S. Herman. 1987. Biogeochemical conditions favoring magnetite formation during anaerobic iron reduction. Appl. Environ. Microbiol. 53:2610-2616.

16. Berner, R. A. 1962. Synthesis and description of tetragonal iron sulfide. Science 137:669.

17. Berner, R. A. 1964. Iron sulfides formed from aqueous solution at low temperatures and atmospheric pressure. J. Geol. 72:293-306.

18. Berner, R. A. 1967. Thermodynamic stability of sedimentary iron sulfides. Am. J. Sci. 265:773785 .

19. Berner, R. A. 1969. The synthesis of framboidal pyrite. Econ. Geol. 64:383-393.

20. Berner, R. A. 1970. Sedimentary pyrite formation. Am. J. Sci. 268:1-23.

21. Berner, R. A. 1974. Iron sulfides in Pleistocene deep Black Sea sedinents and their palacooceanographic significance, p. 524-531. In E. T. Degens and D. A. Ross (ed.), The Black Sea: Geolog.'. Chemistry and Biology. AAPG Memoirs 20. American Association of Petroleum Geologists, Tulsa, Okla.

22. Berson, A. E., D. V. Hudson, and N. S. Waleh. 1991. Cloning of a sequence of Aquaspirillum magnetotacticum that complements the aroD gene of Escherichici coli. Mol. Microbiol. 5:22612264.

23. Berson, A. E., M. R. Peters, and N. S. Waleh. 1989. Cloning and characterization of the recA gene of Aquaspirillum magnetotacticum. Arch. Microbiol. 152:567-571.

24. Berson, A. E., M. R. Peters, and N. S. Waleh. 1990. Nucleotide sequence of recA gene of Aquaspirillum magnetolacticum. Nucleic Acids Res. 18:675.

25. Beveridge, T. J. 1989. Role of cellular design in bacterial metal accumulation and mineralization. Annu. Rev. Microbiol. 43:147-171.

26. Blakemore, R. P. 1975. Magnetotactic bacteria. Science 190:377-379.

27. Blakemore, R. P. 1982. Magnetotactic bacteria. Annu. Rev. Microbiol. 36:217-238.

28. Blakemore, R. P., and N. A. Blakemore. 1990. Magnetotactic magnetogens, p. 51-67. In R. B. Frankel and R. P. Blakemore (ed.), Iron Biominerals. Plenum Press, New York, N.Y.

29. Blakemore, R. P., N. A. Blakemore, D. A. Bazylinski, and T. T. Moench. 1989. Magnetotactic bacteria, p. 1882-1889. In J. T. Staley, M. P. Bryant, N. Pfennig, and J. G. Holt (ed.), Bergey's Manual of Systenatic Bacteriology, vol. 3. The Williams \& Wilkins Co., Baltimore, Md.

30. Blakemore, R, P., R. B. Frankel, and A. J. Kalmijn. 1980. South-seeking magnetotactic bacteria in the southern hemisphere. Nature (Iondon) 236:384-385.

31. Blakemore, R. P., D. Maratea, and R. S. Wolfe. 1979. Isolation and pure culture of a freshwater magnetic spirillum in chenically defined medium. J. Bacteriol. 140:720-729.

32. Blakemore, R. P., K. A. Short, D. A. Bazylinski, C. Rosenblatt, and R. B. Frankel. 1985. Microaerobic conditions are required for magnetite formation within Aquaspirillum magnefotacticum. Gemicrobiol. J. 4:53-71. 
33. Bradley, J. P., R. P. Harvey, and H. Y. McSween, Jr. 1996. Magnetite whiskers and platelets in the ALH84001 martian meteorite: evidence for vapor phase growth. Geochim. Cosmochim. Acta 60: 5149-5155.

34. Burgess, J. G., R. Kanaguchi, T. Sakaguchi, R. H. Thornhill, and T. Matsunaga. 1993. Evolutionary relationships among Magnetospirillum strains inferred from phylogenetic analysis of 165 rRNA sequences. J. Bacteriol. 175:6689-6694.

35. Butler, R. F., and S. K. Banerjee. 1975. Theoretical single-domain grain size range in magnetite and titanomagnetite. I. Geophys. Res. 80:4049-4058.

36. Caccavo, F., Jr., D. J. Lonergan, D. R. Lovley, M. Davis, J. F. Stolz, and M. J. McInerny. 1994 Geobacter sulfurreducens sp. nov, a hydrogen- and acetate-oxidizing dissimilatory metal reducing microorganism. Appl. Environ. Microbiol. 60:3752-3759.

37. Chang, S.-B. R., and J. L. Kirschvink. 1989. Magnetofossils, the magnetization of sediments, and the evolution of magnetite biomineralization. Annu. Rev. Earth Planet. Sci. 17:169-195.

38. Chang, S.-B. R., J. F. Stolz, J. L. Kirschvink, and S. M. Awramik. 1989. Biogenic magnetite in stromatolites. 2. Occurrence in ancient sedimentary environments. Precambrian Res. 43:305-312.

39. Dean, A. J., and D. A. Bazylinski. 1999. Genome analysis of several marine, magnetotactic bacterial strains by pulsed-field gel electrophoresis. Curr. Microbiol. 39:219-225.

40. DeLong, E. F., R. B. Frankel, and D. A. Bazylinski. 1993. Multiple evolutionary origins of magnetotaxis in bacteria. Science 259:803-806.

41. Devouard, B., M. Pósfai, X. Hua, D. A. Bazylinski, R. B. Frankel, and P. R. Buseck. 1998. Magnetite from magnetotactic bacteria: size distributions and twinning. Am. Mineral. 83:1387-1398.

42. Diaz-Ricci, J. C., and J. L. Kirschvink. 1992. Magnetic domain state and coercivity predictions for biogenic greigite $\left(\mathrm{Fe}_{3} \mathrm{~S}_{4}\right)$ : a comparison of theory with magnetosome observations. J. Geophys. Res. 97:17309-17315.

43. DiChristina, T. J., and E. F. DeLong. 1993. Design and application of rRNA-targeted oligonucleotide probes for the dissimilatory iron- and manganese-reducing bacterium Shewanella putrefaciens. J. Bacteriol. 59:4152-4160.

44. Donaghay, P. L., H. M. Rines, and J. M. Sieburth. 1992. Simultaneous sampling of fine scale biological, chemical and physical structure in stratified waters. Arh. Hydrobiol. Beih. Ergebn. Limnol. 36:97-108.

45. Dunin-Borkowski, R. E., M. R. McCartney, R. B. Frankel, D. A. Bazylinski, M. Pósfai, and P. R. Buseck. 1998. Magnetic microstructure of magnetotactic bacteria by electron holography. Science 282:1868-1870.

46. Eden, P. A., T. M. Schmidt, R. P. Blakemore, and N. R. Pace. 1991. Phylogenetic analysis of Acjucispirillum megnetotacticum using polymerase chain reaction-amplified 16 S rRNA-specific DNA. Int. I. Syst. Bacteriol. 41:324-325.

47. Fabricus, F. 1961 . Die Strukturen des "Rogenpyrits" (Kossener Schichten, Rat) als Betrag zum Problem der "Vererzten Bakterien." Geol. Rundschau 51:647-657.

48. Farina, M., D. M. S. Esquivel, and H. G. P. Lins de Barros. 1990. Magnetic iron-sulphur crystals from a magnetotactic microorganism. Nature (London) 343:256-258.

49. Farina, M., H. Lins de Barros, D. M. S. Esquivel, and J. Danon. 1983. Ultrastructure of al magnetotactic bacterium. Biol. Cell 48:85-88.

50. Frankel, R. B. 1984. Magnetic guidance of organisms. Annu. Rev: Biophris. Bioeng. 13:85-103.

51. Frankel, R. B., and D. A. Bazylinski. 1994. Magnetotaxis and magnetic particles in bacteria. Hyperfine Intercict. 90:135-142.

52. Frankel, R. B., D. A. Bazylinski, M. Johnson, and B. L. Taylor. 1997. Magneto-aerotaxis in marine, coccoid bacteria. Biophys. J. 73:994-1000.

53. Frankel, R. B., D. A. Bazylinski, and D. Schüler. 1998. Biomineralization of magnetic iron minerals in bacteria. Supranol. Sci. 5:383-390.

54. Frankel, R. B., R. P. Blakeniore, F. F. Torres de Araujo, D. M. S. Esquivel, and J. Danon. 1981. Magnetotactic bacteria at the geomagnetic equator. Science 212:1269-1270.

55. Frankel, R. B., R. P. Blakemore, and R. S. Wolfe. 1979. Magnetite in freshwater magnetotactio bacteria. Science 203:1355-1356.

56. Frankel, R. B., G. C. Papaefthymiou, R. P. Blakemore, and W. O'Brien. 1983. Fe $\mathrm{O}_{4}$ precipitation in magnetotactic bacteria. Biochim. Biophys. Acta 763:147-159. 
57. Frankel, R. B., J.P. Zhang, and D. A. Bazylinski. 1998. Single magnetic domains in magnetotactic bacteria. I. Geoplys. Res. 103:30601-30604.

58. Freke, A. M., and D. Tate. 1961. The fomation of magnetic iron sulphide by bacterial reduction of iron solutions. J. Biochem. Mircobiol. Technol. Eng. 3:29-39.

59. Tunaki, M., H. Sakai, and T. Matsunaga. 1989. Identification of the magnetic poles on strong magnetic gratins from meteorites using magnetotactic bacteria. \%. Geomagn. Geoelect: 41:77-87.

60. Funaki, M., H. Sakai, T. Matsunaga, and S. Hirose. 1992. The S pole distribution on magnetic grains in pyroxenite determined by magnetotactic bacteria. Phys. Eorth Planet. Interiors 70:253260 .

61. Futschik, K., H. Pfützner, A. Doblander, P. Schönhuber, T. Dobeneck, N. Petersen, and H. Vali. 1989. Why not use magnetotactic bacteria for domain analyses? Phys. S*\% 40:518-521.

62. Gorby, Y. A. 1989. Regulation of Magnetosome Biogenesis by Orygen and Nirogen, p. 72-88. Ph.D. dissertation. University of New Hampshire, Durham.

63. Gorby, Y. A., T. J. Beveridge, and R. P. Blakemore. 1988. Characterization of the bacterial magnetosome membrane. J. Bucteriol. 170:834-841.

64. Greene, A. C., B. K. C. Patel, and A. J. Sheehy. 1997. Deferibacter themophilus gen. nov. sp. nov, a novel thermophilic manganese- and iron-reducing bacterium isolated from a petroleum reservoir. Int. I. Svist. Bacteriol. 47:505-509.

65. Gould, J. L., J. L. Kirschvink, and K. S. Deffeyes. 1978. Bees have magnetic remanence. Science 201: $1026-1028$.

66. Guerin, W. F., and R. P. Blakemore. 1992. Redox cycling of iron supports growth and magnetite synthesis by Aquaspirillam magnitotacticum. Appl. Environ. Microbiol. 58:1102-1109.

67. Guerinot, M. L. 1994. Microbial iron transport. Annu. Rev. Microbiol. 48:743-772.

68. Hanzlik, M. M., N. Petersen, R. Keller, and E. Schmidbauer. 1996. Electron microscopy and ${ }^{57} \mathrm{Fe}$ Mössbauer spectra of $10 \mathrm{~mm}$ particles, intermediate in composition between $\mathrm{Fe}_{3} \mathrm{O}_{4}-\gamma-\mathrm{Fe}_{2} \mathrm{O}_{3}$, produced by bacteril. Geophys. Res. Lent. 23:479-482.

69. Heywood, B. R., D. A. Bazylinski, A. J. Garratt-Reed, S. Mann, and R. B. Frankel. 1990. Controlled biosynthesis of greigite $\left(\mathrm{Fe}_{3} \mathrm{~S}_{4}\right)$ in magnetotactic bacteria. Natumissenschaften 77:536538.

70. Heywood, B. R., S. Mann, and R. B. Frankel. 1991. Siructure, morphology and grow'th of biogenic greigite $\left(\mathrm{Fe}_{3} \mathrm{~S}_{4}\right)$. p. 93-108. In M. Alpert, P. Calvert. R. B. Frankel, P. Rieke, and D. Tirrell (ed.). Marerials Sinthesis Based on Biological Processess. Materials Research Society, Pittsburgh, Pa.

71. Iida, A., and J. Akai. 1996. Crystalline sulfur inclusions in magnetotactic bacteria. Sci. Rep. Niigara Univ: Ser: E 11:35-42.

72. Iida, A., and J. Akai. 1996. TEM study on magnetotactic bacteria and contained magnetite grains as biogenic minerals, mainly from Hokuriku-Niigata region, Japan. Sci. Rep. Nigata Univ. Ser: E 11:43-66.

73. Janvier, B., P. Constantinidou, P. Aucher, Z. V. Marshall, C. W. Penn, and J. L. Fauchère. 1998. Characterization and gene sequencing of a 19-kDa periplasmic protein of Campviobacter jejumil coli. Res. Microbiol. 149:95-107.

74. Kawaguchi, R., J. G. Burgess, T. Sakaguchi, H. Takeyama, R. H. Thornhill, and T. Matsunaga. 1995. Phylogenetic analysis of a novel sulfate-reducing magnetic bacterium, RS-1, demonstrates its membership of the S-Proteobacteria. FEMS Microbiol. Lett. 126:277-282.

75. Kirschvink, J. L. 1980. South-seeking magnetic bacteria. J. Exp. Biol. 86:345-347.

76. Kirschvink, J. L., A. Kobayashi-Kirschvink, and B. J. Woodford. 1992. Magnetite biomineralization in the human brain. Proc. Nall. Acud. Sc\%. USA 89:7683-7687.

77. Kobayashi, A., J. L. Kirschvink. 1995. Magnetoreception and elctromagnetic field effects: sensory perception of the geomagnetic fieid in animals and humans. Adv. Chem. Ser. 250:367-394.

78. Konhauser, K. O. 1998. Diversity of bacterial iron mineralization. Ecirth Sci. Rev. 43:91-121.

79. Kostka, J. E., and K. M. Nealson. 1995. Dissolution and reduction of magnetite by bacteria. Environ. Sci. Technol. 29:2535-2540.

80. Kuterbach, D. A., B. Walcott, R. J. Reeder, and R. B. Frankel. 1982. Iron-containing cells in the honcybee (Apis mellifera). Science 218:695-697. 
81. Liu, S. V., J. Zhou, C. Zhang, D. R. Cole, M. Gajdarziska-Josifovska, and T. J. Phelps. 1997. Themophilic Fe(III)-reducing bacteria from the deep subsurface: the evolutionary implications. Science 277: 1 100-1109.

82. Lohmann, K. J. 1991. Magnetic orientation by hatchling loggerhead sea turtles (Caretta caretta). J. Exp. Biol. 155:37-49.

83. Lohmann, K. J., and A. O. D. Willows. 1987. Lunar-modulated geomagnetic orientation by a marine mollusk. Science 235:331-334.

84. Lonergan, D. J., H. L. Jenter, J. D. Coates, E. J. P. Phillips, T. M. Schmidt, and D. R. Lovley. 1996. Phylogenetic analysis of dissimilatory Fe(III)-reducing bacteria. J. Bacteriol. 178:2402-2408.

85. Love, L. G., and D. O. Zimmerman. 1961. Bedded pyrite and microrganisms from the Mount Isa Shale. Econ. Geol. 56:873-896.

86. Lovley, D. R. 1987. Organic matter mineralization with the reduction of ferric iron: a review. Geomicrobiol. J. 5:375-399.

87. Lovley, D. R. 1990. Magnetite formation during microbial dissimilatory iron reduction, p. 151166. In R. B. Frankel and R. P. Blakemore (ed.), Iron Bioninerals. Plenum Press, New York, N.Y.

88. Lovley, D. R. 1991. Dissimilatory Fe(III) and $\mathrm{Mn}(\mathrm{IV})$ reduction. Microbiol. Rev. 55:259-287.

89. Lovley, D. R., S. J. Giovannoni, D. C. White, J. E. Champine, E. J. P. Phillips, Y. A. Gorby, and S. Goodwin. 1993. Geobacter metallireducens gen. nov. sp. nov, a microorganism capable of coupling the complete oxidation of organic compounds to the reduction of iron and other metals. Arch. Microbiol. 159:336-344.

90. Lovley, D. R., and E. J. P. Phillips. 1988. Novel mode of microbial energy metabolism: organic carbon oxidation coupled to dissimilatory reduction of iron or manganese. Appl. Environ. Microbiol. 54:1472-1480.

91. Lovley D. R., J. F. Stolz, G. L. Nord, Jr., and E. J. P. Phillips. 1987. Anaerobic production of magnetite by a dissimilatory iron-reducing microorganism. Nature (London) 330:252-254.

92. Lowenstam, H. A. 1981. Minerals formed by organisms. Science 211:1126-1131.

93. Maher, B. A. 1990. Inorganic formation of ultratine-grained magnetite, p. 179-192. In R. B. Frankel and R. P. Blakemore (ed.), Iron Biominerals. Plenum Press, New York, N.Y.

94. Maher, B. A., and R. M. Taylor. 1988. Formation of ultra-tine grained magnetite in soils. Nature (London) 336:368-370.

95. Mandernack, K. W., D. A. Bazylinski, W. C. Shanks, and T. D. Bullen. 1999. Oxygen and iron isotope studies of magnelite produced by magnetotactic bacteria. Science 285:1892-1896.

96. Mann, S. 1986. On the nature of boundary-organised biomineralization. I. Inorg. Chem. 28:363371 .

97. Mamn, S., and R. B. Frankel. 1989. Magnetile bionineralization in unicellular organisms, p. 389426. In S. Mann, J. Webb, and R. J. P. Williams (ed.), Biomineralization: Chenical and Biochemical Porspertives. VCH Publishers, New York, N.Y.

98. Mann, S., R. B. Frankel, and R. P. Blakemore. 1984. Structure, morphology and crystal growth of bacterial magnetite. Name (London) 310:405-407.

99. Manu, S., T. T. Moench, and R. J. P. Williams. 1984. A high resolution electron microscopic investigation of bacterial mignecite. [mplications for crystal growth. Proc. R. Soc. Lond. Sec. B B $221: 385-393$

100. Mann, S., N. H. C. Sparks, and R. P. Blakemore. 1987. Ulirastructure and characterization of anisotropic inclusions in magnetotactic bacteria. Proc. R. Soc. Lond. Sor. B 231:469-476.

101. Mann, S., N. H. C. Sparks, and R. P. Blakemore. 1987. Structure, morphology and crystal growth of anisotropic magnetite crystals in magnetotactic bacteria. Proc. R. Soc. Lond. Ser. B 231:477487.

102. Mann, S., N. H. C. Sparks, and R. G. Board. 1990. Magnetolactic bacteria: microbiology. biomineralization, palaeomagnetism, and biotechnology. Adv. Microb. Phriol. 31:125-181.

103. Mann, S., N. H. C. Sparks, S. B. Couling, M. C. Larcombe, and R. B. Frankel. 1989. Crystallochemical characterization of magnetic spinels prepared from aqueous solution. $I$. Chom. Sor. Faraday Trans. 85:3033-3044

104. Mann, S., N. H. C. Sparks, R. B. Frankel, D. A. Bazylinski, and H. W. Jauuasch. 1990. Biomineralization of ferrimagnetic greigite $\left(\mathrm{Fe}_{3} \mathrm{~S}_{2}\right)$ and iron pyrite $\left(\mathrm{FeS}_{2}\right)$ in a magnetotactic bacterium. Nature (London) 343:258-260. 
105. Manson, M. D. 1992. Bacterial chemotaxis and motility. Adv. Micob. Phisiol. 33:277-346.

106. Maratea, D., and R. P. Blakemore. 1981. Aquatipinillum magnetoracticum sp. nov, a magnetic spirillum. Int. I. Syst. Bucteriol. 31:452-455.

107. Matitashvili, E. A., D. A. Matojan, T. S. Gendler, T. V. Kurzchalia, and R. S. Adamia. 1992. Magnetolictic bacteria from freshwater lakes in Georgia. J. Bosic Microbiol. 32:185-192.

108. Matsuda, T, I. Endo, N. Osakabe, A. Tonomura, and T. Arii. 1983. Morphology and structure of biogenic magnetite particles. Nature (London) 302:411-412.

109. Matsunaga, T. 1991. Applications of bacterial magnets. Thends Biotechnol. 9:91-95.

110. Matsunaga, T., K. Hashimoto, N. Nakamura, K. Nakamura, and S. Hashimoto. 1989. Phagocylosis of bacterial magnetite by leucocytes. Appl. Microbiol. Bioteclmel. 31:401-405.

111. Matsunaga, T., and S. Kamiya, 1987. Use of magnetic particles isolated from magnetotactic bacteria for enzyme mobilization. Appl. Microbiol. Biotechnol. 26:328-332.

112. Matsunaga, T., C. Nakamura, J. G. Burgess, and K. Sode. 1992. Gene transfer in magnetic bacteria: transposon mutagenesis and cloning of genomic DNA fragments required for magnetitc synthesis. J. Bucteriol. 174:2748-2753.

113. Matsunaga, T., T. Sakaguchi, and F. Tadokoro. 1991. Magnetite formation by a magnelic bacterium capable of growing aerobically. Appl. Microbiol. Biotechnol. 35:651-655.

14. Matsunaga, T., F. Tadokoro, and N. Nakamura. 1990. Mass culture of magnetic bacteria and their application to flow type immunoassays. IEEE Trans. Magn. 26:1557-1559.

115. Matsunaga, T., and N. Tsujimura. 1993. Respiratory inlubitors of a magnetic bacterium Mag. netospirilltm sp. AMB-1 capable of growing aerobically. Appl. Microbiol. Biotechnol. 39:368-371

1 16. MeFadden, B. A., and J. M. Shively. 1991. Bacterial assimilation of carbon dioxide by the Calvin cycle, p. 25-49. In J. M. Shively and L. L. Barton (ed.). Variations in Autorrophic Life. Academic Press, Inc., San Diego, Calif.

117. McKay, D. S., E. K. Gibson Jr., K. L. Thomas-Keprta, H. Vali, C. S. Romanek, S. J. Clemett, X. D. F. Chillier, C. R. Maechling, and R. N. Zare. 1996. Search for past life on Mars: possible relic biogenic activity in Martian meteorite ALH84001. Science 273:924-930.

1 8. Meldrum, F. C., B. R. Heywood, S. Mann, R. B. Frankel, and D. A. Bazylinski. 1993. Eleciron microscopy study of magnetosomes in two cultured vibrioid magnetotactic bacteria. Proc. $R$. Sor. Lond. Ser: B 251:237-242.

119. Meldrum, F. C., B. R. Heywood, S. Mann, R. B. Frankel, and D. A. Bazylinski. 1993. Ejectron microscopy study of magnetosones in a cultured coccoid magnetotactic bacterium. Proc. R. Soc: Lond. Ser: B 251:231-236.

120. Moench, T. T. 1988. Biliphococcus magnetolacticus gen. nov. sp. nov, a motile, magnetic coccus. Antonie Leewwenlioek 54:483--496.

121. Moench, T. T., and W. A. Konetzka. 1978. A novel method for the isolation and study of a magnetic bacterium. Arch. Microbiol. 119:203-212.

122. Moskowitz, B. M. 1995. Biomineralization of magnetic minerals. Rev. Geophys. Suppl. 33:123128.

123. Moskowitz, B. M., R. B. Frankel, D. A. Bazylinski. 1993. Rock magnetic criteria lor the detection of biogenic magnetite. Earth Planet. Sci. Lett. 120:283-300.

124. Moskowitz, B. M., R. B. Frankel, D. A. Bazylinski, H. W. Jannasch, and D. R. Lovley. 1989. A comparison of magnetite particles produced anaerobically by magnetotactic and dissimilatory iron-reducing bacteria. Geophys. Res. Letr. 16:665-668.

125. Myers, C. R., and K. H. Nealson. 1990. Iron mineralization by bacteria: metabolic coupling of iron reduction to cell metabolism in Alteromonas putrefacien.: MR-1, p. 131-149. In R. B. Frankej and R. P. Blakemore (ed.), Iron Biominerals. Plenum Press, New York, N.Y.

126. Nakamura, C., J. G. Burgess, K. Sode, and T. Matsunaga. 1995. An iron-regulated gene, magA, encoding an iron transport protein of Magnetospirillum AMB-1. J. Bioi. Chem. 270:28392-28396.

127. Nakamura, C., T. Kikuchi, J. G. Burgess, and T. Matsunaga. 1995. Iron-regulated expression and membrate localization of the MagA protein in Magnetospirillum sp. strain AMB-1. J. Biochem. $118: 23-27$.

128. Nakamura, C., T. Sakaguchi, S. Kudo, J. G. Burgess, K. Sode, and T. Matsunaga. 1993. Characterization of iron uptake in the magnetic bacterium Aquaspirillum sp. AMB-1. Appl. Biochem. Biotechnol. 39/40:169-176. 
129. Nakamura, N., J. G. Burgess, K. Yagiuda, S. Kudo, T. Sakaguchi, and T. Matsunaga. Detection and removal of Escherichia coli using fuorescein isothiocyanate conjugated monoclonal antibody immobilized on bacterial magnetic particles. Anal. Chem. 65:2036-2039.

130. Nakamura, N., K. Hashimoto, and T. Matsunaga. 1991. Immunoassay method for the determination of immunoglobulin $G$ using bacterial magnetic particles. Anal. Chem. 63:268-272.

131. Nakamura, N., and T. Matsunaga. 1993. Highly sensitive detection of allergen using bacterial magnetic particles. And. Chim. Acra 281:585-589.

132. Neilands, J. B. 1984. A brief history of iron metabolism. Biol. Metals 4:1-6.

133. Noguchi, Y., T. Fujiwara, K. Yoshimatsu, and Y. Fukumori. 1999. Iron reductase for magnetite synthesis in the magnetotactic bacterium Magnetospirillam magnetotacticam. J. Bacteriol. 181: 2142-2147.

134. Oberhack, M., R. Süssmuth, and F. Hermann. 1987. Magnetotactic bacteria from freshwater. $Z$. Noturforsch. Ser: 42E:300-306

135. O'Brien, W., L. C. Paoletti, and R. P. Blakemore. 1987. Spectal analysis of cytochromes in Aquaspirillum magnetotacticum. Curr. Microbiol. 15:121-127.

136. Okuda, Y., K. Denda, and Y. Fukumori. 1996. Cloning and sequencing of a gene encoding a new nember of the tetratricopeptide protein family from magnetosomes of Magnetospirillum mag netotuticum. Gene 171:99-102.

137. Oldfield, F. 1992. The source of fine-grained magnetite in sediments. Holocene 2:180-182.

138. Palache, C., H. Berman, and C. Frondel. 1944. Dana's Systen of Mineralogy John Wiley \& Sons, Inc., New York, N.Y.

139. Paoletti, L. C., and R. P. Blakemore. 1986. Hydroxamate production by Acfuaspirillam magnetolacticum. J. Bacteriol 167:73-76.

140. Paoletti, L. C., and R. P. Blakemore. 1988. Iron reduction by Aquaspirillum magnetolacticum. Curr: Microbiol. 17:339-342.

141. Peck, J. A., and J. W. King. 1996. Magnetofossils in the sediments of Lake Baikal, Siberia. Earth Planet. Sci. Lett. 140:159-172.

142. Penninga, I., H. deWaard, B. M. Moskowitz, D. A. Bazylinski, and R. B. Frankel. 1995. Remanence curves for individual magnetotactic bacteria using a pulsed magnetic field. $I$. Magn. Magn. Mater: 149:279-286.

143. Petersen, N., T. von Dobeneck, and H. Vali. 1986. Fossil bacterial magnetite in deep-sea sediments from the South Atlantic Ocean. Nature (London) 320:61 1-615.

144. Phillips, J. B. 1986. Two magnetoreception pathways in a migratory salamander. Science 233: $765-767$.

145. Pósfai, M., P. R. Buseck, D. A. Bazylinski, and R. B. Frankel. 1998. Reaction seguence of iron sulfide minerals in bacteria and their use as bionarkers. Science 280:880-883.

146. Pósfai, M., P. R. Buseck, D. A. Bazylinski, and R. B. Frankel. 1998. Iron sulfides from matgnetotactic bacteria: structure, compositions, and phase transitions. Am. Mineral. 83:1469-1481

147. Proksch, R. B., B. M. Moskowitz, E. D. Dahlberg, T. Schaeffer, D. A. Bazylinski, and R. B. Frankel. 1995. Magnetic lorce microscopy of the submicron magnetic assembly in a magnetotactio bacterium. Appl. P/rs. Lett. 66:2582-2584.

148. Rickard, D. T. 1969. The microbiological formation of iron sulfides. Stocth. Contrib. Geol. 20: $50-66$

149. Rickard, D. T. 1969. The chemistry of iron sulfide fomation at low temperatures. Strkh. Contrih. Geol. 20:6?-95.

150. Rogers, F. G., R. P. Blakemore, N. A. Blakemore, R. B. Frankel, D. A. Bazylinski, D. Maratea, and C. Rogers. 1990. Intercellular structure in a many-celled magnetotactic procaryole. Arh. Microbiol. 154:18-22.

151. Rogers, F. G., R. P. Blakemore, N. A. Blakemore, R. B. Frankel, D. A. Bazylinski, D. Maratea, and C. Rogers. 1990. Intercellular junctions, motility and magnetosome structure in a multicellular malgnetotactic procaryote, p. 239-255. In R. B. Frankel and R. P. Blakemore (ed.) fron Biominerals. Plenum Press, New York, N.Y.

152. Rossello-Mora, R. A., F. Caccavo Jr., K. Osterlehner, N. Springer, S. Spring, D. Schüler, W. Ludwig, R. Anann, M. Vannacamneyt, and K.-H. Schleifer. 1994. Lsolation and taxomomic 
characterization of a halotolerant, facultative anaerobic iron-reducing bacterium. Syst. Appl. Microbiol. 17:569-573.

153. Sakaguchi, T., J. G. Burgess, and T. Matsunaga. 1993. Magnetite formation by a sulphatereducing bacterium. Nature (London) 365:47-49.

154. Sakaguchi, H., H. Hagiwara, Y. Fukumori, Y. Tamaura, M. Funaki, and S. Hirose. 1993. Oxygen concentration-dependent induction of a ]40-kDa protein in magnetic bacterium Magnetospirillum magnetotacticum MS-1. FEMS Microbiol. Letl. 107:169-174.

155. Schleifer, K.-H., D. Schüler, S. Spring, M. Weizenegger, R. Amann, W. Ludwig, and M. Kohler. 1991. The genus Magnetospirillum gen. nov., description of Magnetospirillum gryphiswaldense sp. nov., and transfer of Aquaspirillum magnetotaticum to Magnetospirillum magnetofacticum comb. nov. Syst. Appl. Microbiol. 14:379-385.

156. Schüler, D., and $\mathbb{E}$. Baeuerlein. 1996. Iron-limited growth and kinetics of iron uptake in Magnetospirillum gryphiswaidense. Arch. Microbiol. 166:301-307.

157. Schüler, D., and E. Baeuerlein. 1998. Dynamics of iron uptake and $\mathrm{Fe}_{3} \mathrm{O}_{4}$ mineralization during aerobic and microaerobic growth of Magnelospirillum gryphiswaldense. J. Bacteriol. 180:159-162.

158. Schüler, D., S. Spring, and D. A. Bazylinski. 1999. Improved technique for the isolation of magnetotactic spirilla from a treshwater sediment and their phylogenetic characterization. Syst. Appl. Microbiol 22:466-471.

159. Segall, J. E., S. M. Block, and H. C. Berg. 1986. Temporal comparisons in bacterial chemotaxis. Proc. Nall. Acad. Sci. USA 83:8987-8991

160. Short, K. A., and R. P. Blakemore. 1986. Iron respiration-driven proton translocation in alerobic bacteria. J. Bucteriol. 167:729-731.

161. Short, K. A., and R. P. Blakemore. 1989. Periplasmic superoxide dismutases in Aquaspirillum magnetotacticum. Arch. Microbiol. 152:342-346.

162. Silverman, M., and M. Simon. 1974. Flagellar rotation and the mechanism of bacterial motility. Nature (London) 249:73-74.

163. Slobodkin, A. I., C. Jeanthon, S. L'Haridon, T. Nazina, M. Miroschnichenko, and E. BonchOsmolovskaya. 1999. Dissimilatory reduction of Fe(III) by thermophilic bacteria and archaea in deep subsurface petroleum reservoirs of western Siberia. Curr. Microbiol. 39:99-102.

164. Slobodkin, A. I., A.-L. Reysenbach, N. Strutz, M. Dreier, and J. Wiegel. 1997. Themolerrabacterium ferrireducens gen. nov., sp. nov., al thermophilic anacrobic dissimilatory Fe(III)-reducing bacterium from a continental hot spring. Int. J. Syst. Bacteriol. 47:541-547.

165. Sparks, N. H. C. 1990. Structural and morphological characterization of biogenic magnetite crystals, p. 167-177. In R. B. Frankel and R. P. Blakemore (ed,) Iron Biominerals. Plenum Press, New York, N.Y.

166. Sparks, N. H. C., S. Mann, D. A. Bazylinski, D. R. Lovley, H. W. Jannasch, and R. B. Frankel. 1990. Structure and morphology of magnetite anaerobically-produced by a marine magnetotactic bacterium and a dissinilatory iron-reducing bacterium. Eurth Plonet. Sci. Lett. 98:14-22.

167. Spormann, A. M., and R. S. Wolfe. 1984. Chemotactic, magnetotactic and tactile behavior in at magnetic spirillum. FEMS Microbiol. Letl. 22:171-177.

168. Spring, S., R. Amann, W. Ludwig, K.-H. Schleifer, H. van Gemerden, and N. Petersen. 1993. Dominating role of an unusual magnetotactic bacterium in the microaerobic zone of a freshwater sediment. Appl. Environ. Microbiol. 59:2397-2403.

169. Spring, S., R. Amann, W. Ludwig, K.-H. Schleifer, and N. Petersen. 1992. Phylogenetic diversity and identification of non-culturable magnetotactic bacteria. Syst. Appl. Microbiol. 15:116-122.

170. Spring, S., R. Amann, W. Ludwig, K.-H. Schleifer, D. Schüler, K. Poralla, and N. Petersen. 1994. Phylogenetic analysis of uncultured magnetotactic bacteria from the alpha-subclass of Proteobacteria. Syst. Appl. Microbiol. 17:501-508.

171. Spring, S., U. Lins, R. Amann, K.-H. Schleifer, L. C. S. Ferreira, D. M. S. Esquivel, and M. Farina. 1998. Phylogenetic affiliation and ultrastructure of uncultured magnetic bacteria with unusually large nagnetosomes. Arch. Microbiol. 169:136-147.

172. Spring, S., and K.-H. Schleifer. 1995. Diversily of magnetolactic bacteria. Syst. Appl. Microbiol. 18: $147-153$

173. Stolz, J. F. 1993. Magnetosones. J. Gen Microbiol. 139:!663-1670. 
174. Stolx, J. F., S.-B. R. Chang, and J. L. Kirschvink. 1986. Magnetotactic bacteria and single domain magnetite in hemipelagic sediments. Nature (London) 321:849-850.

175. Stolz, J. F., D. R. Lovley, and S. E. Haggerty. 1990. Biogenic magnetite and the magnetization of sediments. J. Geophys. Res. 95:4355-4361.

176. Suzuki, H., T. Tanaka, T. Sasaki, N. Nakamura, T. Matsunaga, and S. Mashiko. 1998. High resolution magnetic force microscope images of a magnetic particle chain extracted from magnetic bacteria AMB-1. Ipn. J. Appl. Phys. 37:L1343-L1345.

177. Swancutt, M. A., B. S. Riley, J. D. Radolf, and M. V. Norgard. 1989. Molecular characterization on the pathogen-specific, 34-kilodalton membrane immunogen of Triponema pallidum. Infect. Immun. 57:3314-3323.

178. Tamegai, H., and Y. Fukumori. 1994. Purification, and some molecular and enzymatic features of a novel acb-type cytochrome $c$ oxidase from a microaerobic denitrifier, Magnetospirillim magnetoicticum. FEBS Lett. 347:22--26.

179. Tamegai, H., T. Yamanaka, and Y. Fukumori. 1993. Purification and properties of a "cytochrome $a_{1}$ "-like hemoprotein from a magnetotactic bacterium, Aquaspirillum magnetotacticum. Biochim. Bioplins. Actu 1158:237-243.

180. Taylor, B. L. 1983. How do bacteria find the optimal concentration of oxygen? Trends Biochem. Sci. 8:438-441.

181. Thornhill, R. H., J. G. Burgess, T. Sakaguchi, and T. Matsunaga. 1994. A morphological classification of bacteria containing bullet-shaped magnetic particles. FEMS Microbiol. Leth. 115: $169-176$.

182. Torres de Araujo, F. F., M. A. Pires, R. B. Frankel, and C. E. M. Bicudo. 1986. Magnetite and magnetotaxis in algae. Biophys. J. 50:385-378.

183. Towe, K. M., and T. T. Moench. 1981. Electron-optical characterization of bacterial magnetite. Earth Plenet. Sci. Lett. 52:213-220.

184. van Vliet, A. H., K. G. Woolridge, and J. M. Ketley. 1998. Iron-responsive gene regulation in a Campylobacter jejuni fur mutant. I. Bacteriol. 180:5291-5298.

185. Vargas, M., K. Kashefi, E. L. Blunt-Harris, and D. R. Lovley. 1998. Microbiological evidence for Fe(III) reduction on early Earth. Nature (London) 395:65-67.

186. Wakeham, S. G., B. L. Howes, and J. W. H. Dacey. 1984. Dimethyl sulphide in a stratified coastal salt pond. Nature (London) 310:770-772.

187. Wakeham, S. G., B. L. Howes, J. W. H. Dacey, R. P. Schwarzenbach, and J. Zeyer. 1987. Biogeochemistry of dimethylsulfide in a seasonally stratified coastal salt pond. Geotim. Cosmochim. Acta 51:1675-1684.

188. Walcott, C., J. L. Gould, and J. L. Kirschvink. 1979. Pigeons have magnets. Science 205:10271029.

189. Walcott, C., and R. P. Green. 1974. Orientation of homing pigeons altered by a change in the direction of an applied magnetic field. Science 184:108-182

190. Waleh, N. S. 1988. Functional expression of Aguaspirillum magnetotacticum genes in Escherichia coli K12. Mot. Gen. G'net. 214:592-594

191. Walker, M. M., and M. E. Bitterman. 1989. Honeybees can be trained to respond to very small changes in geomagnetic field intensity. I. Exy. Biol. 145:489-494.

192. Walker, M. M., C. E. Diebel, C. V. Haugh, P. M. Pankhurst, and J. C. Montgomery. 1997. Structure and function of the vertebrate magnetic sense. Nature 390:371-376.

193. Walker, M. M., J. L. Kirschvink, A. E. Dizon, and G. Ahmed. 1992. Evidence that fin whales respond to the geomagnetic field during migration. I. Exp. Biol. 171:67-78.

194. Woese, C. R. 1987. Bacterial evolution. Microbiol. Rev: 51:221-271.

195. Yamazaki, T., H. Oyanagi, T. Fujiwara, and Y. Fukumori. 1995. Nitrite reductase from the magnetotactic bacterium Magnetospirillum magnetotacticum: a novel cytochrome cd, with Fe(li): nitrite oxidoreductuse activity. Eur. I. Biochem. 233:665-671.

196. Zavarzin, G. A., E. Stackebrandt, and R. G. E. Murray. 1991. A correlation of phylogenetic diversity in the Proteobacteria with the influences of ecological forces. Cam. I. Microbiol. 37:1-6.

197. Zhang, C., S. Liu, T. J. Phelps, D. R. Cole, J. Horita, and S. M. Fortier 1997. Physiochemical. mineralogical. and isotopic characterization of magnetite-rich iron oxides formed by themophilic iron-reducing bacteria. Geochim. Cosmochim. Acto 61:462!-4632. 
198. Zhang, C., H. Vali, C. S. Romanek, T. J. Phelp, and S. V. Lu. 1998. Formation of single domain magnetite by a thermophilic bacterium. Am. Mineral. 83:1409-1418.

199. Zhulin, I. B., Y. A. Bespelov, M. S. Johnson, and B. L. Taylor. 1996. Oxygen taxis and proton motive force in A-ospirillum brasiliense. J. Bacteriol. 178:5199-5204. 